Article

\title{
Environmental and Oceanographic Conditions at the Continental Margin of the Central Basin, Northwestern Ross Sea (Antarctica) Since the Last Glacial Maximum
}

\author{
Fiorenza Torricella ${ }^{1, *}$, Romana Melis ${ }^{2}{ }^{D}$, Elisa Malinverno ${ }^{3}$, Giorgio Fontolan ${ }^{2} \mathbb{D}_{\text {, Mauro Bussi }}{ }^{2}$, \\ Lucilla Capotondi ${ }^{4}\left(\mathbb{D}\right.$, Paola Del Carlo ${ }^{5} \mathbb{D}$, Alessio Di Roberto ${ }^{5}$, Andrea Geniram ${ }^{2} \mathbb{D}$, Gerhard Kuhn ${ }^{6} \mathbb{D}$, \\ Boo-Keun Khim ${ }^{7}$, Caterina Morigi ${ }^{1}$ (D), Bianca Scateni ${ }^{1,5}$ and Ester Colizza ${ }^{2, *(D)}$
}

1 Dipartimento di Scienze della Terra, Università di Pisa, Via Santa Maria 53, 56126 Pisa, Italy; caterina.morigi@unipi.it (C.M.); bianca.scateni@ingv.it (B.S.)

2 Dipartimento di Matematica e Geoscienze, Università di Trieste, Via E. Weiss 2, 34128 Trieste, Italy; melis@units.it (R.M.); fontolan@units.it (G.F.); bussi@units.it (M.B.); andrea.geniram@phd.units.it (A.G.)

3 Dipartimento di Scienze dell'Ambiente e della Terra, Università di Milano-Bicocca, Piazza della Scienza 4, 20126 Milano, Italy; elisa.maliverno@unimib.it

4 Istituto di Scienze Marine-Consiglio Nazionale delle Ricerche ISMAR-CNR, Via P. Gobetti 101, 40129 Bologna, Italy; lucilla.capotondi@bo.ismar.cnr.it

check for

updates

Citation: Torricella, F.; Melis, R.; Malinverno, E.; Fontolan, G.; Bussi, M.; Capotondi, L.; Del Carlo, P.; Di Roberto, A.; Geniram, A.; Kuhn, G.; et al. Environmental and Oceanographic Conditions at the Continental Margin of the Central Basin, Northwestern Ross Sea (Antarctica) Since the Last Glacial Maximum. Geosciences 2021, 11, 155. https://doi.org/10.3390/ geosciences 11040155

\section{Academic Editors:}

Jesus Martinez-Frias and Angelos G. Maravelis

Received: 26 February 2021

Accepted: 26 March 2021

Published: 31 March 2021

Publisher's Note: MDPI stays neutral with regard to jurisdictional claims in published maps and institutional affiliations.

Copyright: (c) 2021 by the authors. Licensee MDPI, Basel, Switzerland. This article is an open access article distributed under the terms and conditions of the Creative Commons Attribution (CC BY) license (https:// creativecommons.org/licenses/by/ $4.0 /)$.
5 Istituto Nazionale di Geofisica e Vulcanologia, Sezione di Pisa, Via C. Battisti 53, 56125 Pisa, Italy; paola.delcarlo@ingv.it (P.D.C.); alessio.diroberto@ingv.it (A.D.R.)

6 Alfred Wegener Institute Helmholtz Centre for Polar and Marine Research, Am Alten Hafen 26, 27568 Bremerhaven, Germany; gerhard.kuhn@awi.de

7 Department of Oceanography, Pusan National University, Busan 46241, Korea; bkkhim@pusan.ac.kr

* Correspondence: fiorenza.torricella@phd.unipi.it (F.T.); colizzae@units.it (E.C.)

\begin{abstract}
The continental margin is a key area for studying the sedimentary processes related to the advance and retreat of the Ross Ice Shelf (Antarctica); nevertheless, much remains to be investigated. The aim of this study is to increase the knowledge of the last glacial/deglacial dynamics in the Central Basin slope-basin system using a multidisciplinary approach, including integrated sedimentological, micropaleontological and tephrochronological information. The analyses carried out on three box cores highlighted sedimentary sequences characterised by tree stratigraphic units. Collected sediments represent a time interval from $24 \mathrm{ka}$ Before Present (BP) to the present time. Grain size clustering and data on the sortable silt component, together with diatom, silicoflagellate and foraminifera assemblages indicate the influence of the ice shelf calving zone (Unit 1, 24-17 ka BP), progressive receding due to Circumpolar Deep Water inflow (Unit 2, 17-10.2 ka BP) and (Unit 3, $10.2 \mathrm{ka} \mathrm{BP}$-present) the establishment of seasonal sea ice with a strengthening of bottom currents. The dominant and persistent process is a sedimentation controlled by contour currents, which tend to modulate intensity in time and space. A primary volcanic ash layer dated back at around $22 \mathrm{ka} B P$ is correlated with the explosive activity of Mount Rittmann.
\end{abstract}

Keywords: diatoms; micropaleontology; sedimentology; cryptotephra; LGM to Holocene; Central Basin; Western Ross Sea; Antarctica

\section{Introduction}

The high-latitude continental margins are key areas where the sedimentary processes are influenced by the advance and retreat of the ice shelf and by different bottom water current activity on the continental slope between the glacial and interglacial periods [1-3].

The Ross Sea continental margins record the variation of the Antarctic Ice Sheet (AIS) due to the presence of the largest ice shelf, the Ross Ice Shelf (RIS), which promotes the production of dense shelf water which is the precursor for Antarctic Bottom Waters (AABW) [4]. The RIS dynamics that occurred during the Pleistocene and Holocene have 
been extensively studied in the continental shelf (e.g., [5-9]), whereas the marginal areas including the continental slope and rise area, have been less investigated (e.g., [10-16]).

AIS and ice shelves are markedly sensitive to climate change and the study of their past response to climate/environment variations is useful for modelling and prediction of future sea level change [17-21].

The Central Basin forms a deep semi-closed tectonic depression located at the mouth of the JOIDES Basin, along the northwestern margin of the Ross Sea continental shelf. This basin is characterised by different morphological sectors as reported by [3]: the JOIDES mouth and relative continental slope, the intra-slope basin, the ponded basin, located in the south-eastern upper slope, the Central Basin floor and the topographic highs (Iselin Bank to the east, Hallett Ridge to the west, Bank A to the south and Bank B to the north). The Scott Canyon connects the Central Basin to the deep ocean (Figure 1). The semi-closed configuration of the Central Basin favoured the development of conturites associated with the westward-flowing along-slope bottom current [3].

From the oceanographic point of view, the relatively warm Circumpolar Deep Water (CDW) enters into the Central Basin flowing as the modified CDW on the continental shelf where it mixes with the dense shelf water, the High Salinity Shelf Water (HSSW). A branch of the HSSW descends into continental slope through the JOIDES Basin forming the Antarctic Bottom Water (AABW) [22,23].

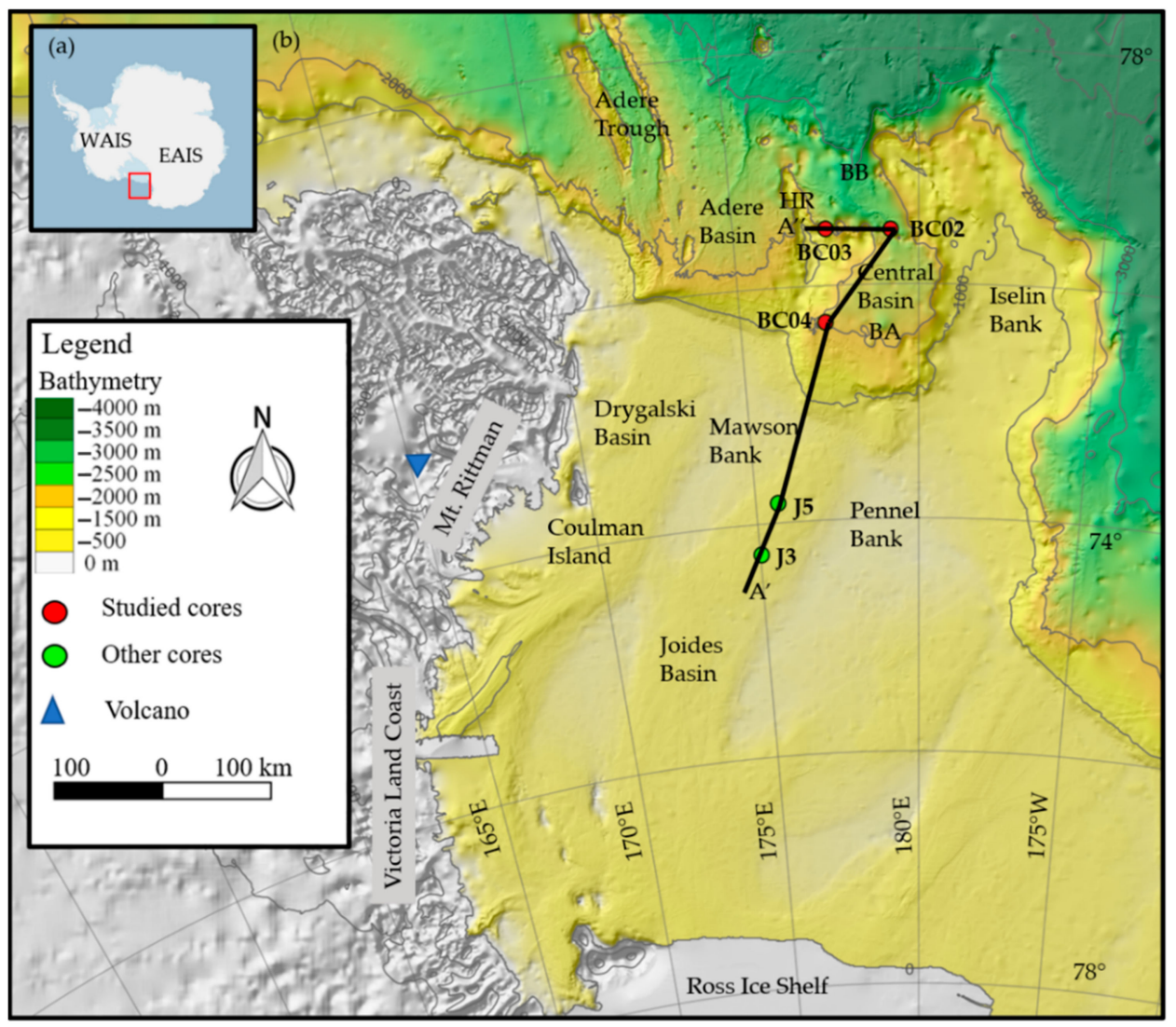

Figure 1. Bathymetric map of the Ross Sea (modified from [24]). WAIS = West Antarctic Ice Sheet, EAIS = Eastern Antarctic Ice Sheet. The red rectangle indicates the studied area. $\mathrm{HR}=$ Hallett Ridge, $\mathrm{BA}=$ Bank $\mathrm{A}, \mathrm{BB}=\mathrm{Bank} \mathrm{B}$. Red dots indicate the studied box cores: $\mathrm{BC} 02=\mathrm{KI} 13-\mathrm{BC} 02 ; \mathrm{BC03}=\mathrm{KI} 13-\mathrm{BC} 03 ; \mathrm{BC} 04=\mathrm{KI} 13-\mathrm{BC} 04$. Green dots indicate cores J5 (ANTA99 $-\mathrm{cJ5}$ ) and J3 (ANTA99-CJ3) studied by [25]. The black line is the axis for the schematic model presented in Section 4.3.

This study aims to increase the understanding of the last glacial and deglacial dynamics in the Central Basin slope-basin system, which is an ideal region for studying the oceanographic variations in relation to the RIS dynamics. We used three box cores located in different morphological settings and at different water depths, to highlight the 
variations in time and space of the environmental changes recorded by the studied sedimentary sequence, using an integrated analysis of sedimentological, micropaleontological and tephrochronological.

We investigated how the different micropaleontological indicators, together with other proxies, respond to the main environmental/climatic variations. This study allows us to provide the spatial and temporal evolution of the most important environmental and oceanographic phases.

\section{Materials and Methods}

The three-box cores, $\mathrm{KI} 13-\mathrm{BC} 02$, $\mathrm{KI} 13-\mathrm{BC} 03$, and $\mathrm{KI} 13-\mathrm{BC} 04$ (hereafter $\mathrm{BC} 02$, BC03 and $\mathrm{BC} 04$ ) were collected during the KOPRI ANA03B cruise onboard the IBRV ARAON in February 2013 in the framework of the scientific cooperation between Korea and Italy (K-PORT and PNRA/ROSSLOPE Projects) (Table 1, Figure 1 [24,25]). The box cores were split, described and x-rayed at the Department of Mathematics and Geosciences (Trieste). Sediment colours were based on the Munsell colour chart.

Table 1. List of core locations, core length and water depth.

\begin{tabular}{ccccc}
\hline Core ID & Latitude S & Longitude E & Water Depth $(\mathrm{m})$ & Length $(\mathbf{c m})$ \\
\hline KI13-BC2 & $71^{\circ} 21.00$ & $179^{\circ} 30.33$ & 2246 & 37 \\
KI13-BC3 & $71^{\circ} 52.47$ & $177^{\circ} 48.08$ & 1800 & 37 \\
KI13-BC4 & $72^{\circ} 32.87$ & $177^{\circ} 33.43$ & 1788 & 45 \\
\hline
\end{tabular}

\subsection{Chronology}

The chronology of the studied box-cores is based on the thirteen Accelerator Mass Spectrometry (AMS) radiocarbon dates performed at the Poznań Radiocarbon Laboratory, Adam Mickiewicz University (Poland) and with the MICADAS [26] at the Alfred-WegenerInstitut Helmholtz-Zentrum für Polar-und Meeresforschung (AWI, Germany). Eleven AMS radiocarbon analyses were carried out using acid insoluble organic matter (AIOM) and two were carried out on N. pachyderma tests (Table 2). Uncorrected and calibrated ${ }^{14} \mathrm{C}$ data are summarised in Table 2. 


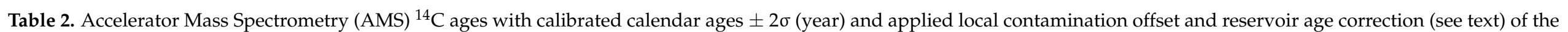

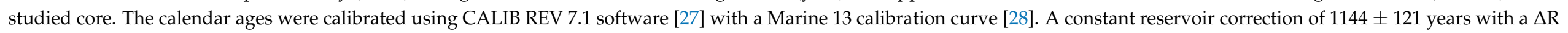
of $791 \pm 121$ years [29] was applied.

\begin{tabular}{|c|c|c|c|c|c|c|c|c|c|c|}
\hline $\begin{array}{l}\text { Box Core } \\
\text { Label }\end{array}$ & $\begin{array}{c}\text { Sample } \\
\text { Depth (cm) }\end{array}$ & $\begin{array}{l}\text { Carbon } \\
\text { Source }^{a}\end{array}$ & $\begin{array}{l}\text { Laboratory } \\
\text { Code }\end{array}$ & $\begin{array}{c}\text { Conventional }{ }^{14} \mathrm{C} \\
\text { Age (year BP) }\end{array}$ & Error (year) & $\mathrm{LCO}^{\mathrm{b}}$ & $\begin{array}{c}\text { LCO Corr. } \\
\text { Age (year BP) }\end{array}$ & $\begin{array}{c}\text { Median } \\
\text { Probability Cal } \\
\text { Age (year BP) }\end{array}$ & $\begin{array}{c}\text { Lower Cal } \\
\text { Range (year BP) }\end{array}$ & $\begin{array}{c}\text { Upper Cal } \\
\text { Range (year BP) }\end{array}$ \\
\hline KI-13 BC02 & $0-1$ & AIOM & OS-107476 & 4140 & & & & 0 & & \\
\hline KI-13 BC02 & $15-16$ & AIOM & Poz-121677 & 16,330 & 100 & 3040 & 13,290 & 14,006 & 13,585 & 14,642 \\
\hline KI-13 BC02 & 18-19 & AIOM & Poz-121678 & 17,010 & 110 & 3040 & 13,970 & 15,209 & 14,476 & 15,776 \\
\hline KI-13 BC02 & $26-27$ & AIOM & Poz-121679 & 17,930 & 120 & 3040 & 14,890 & 16,546 & 16,058 & 17,063 \\
\hline KI-13 BC03 & $0-1$ & AIOM & Poz-69634 & 5050 & & & & 0 & & \\
\hline KI-13 BC03 & $27-28$ & N. pachy & 4814.1.1 & 14,421 & 122 & - & - & 15,878 & 15,315 & 16,332 \\
\hline KI-13 BC03 & $33-34$ & N. pachy & 4815.1 .1 & 15,596 & 136 & - & - & 17,537 & 17,044 & 17,979 \\
\hline KI-13 BC04 & $0-1$ & AIOM & OS-107477 & 4500 & & & & 0 & & \\
\hline KI-13 BC04 & $10-11$ & AIOM & 4807.1.1 & 16,167 & 217 & 3400 & 12,767 & 13,451 & & \\
\hline KI-13 BC04 & $16-17$ & AIOM & Poz-121674 & 17,100 & 110 & 3400 & 13,700 & 14,692 & 14,106 & 15,239 \\
\hline KI-13 BC04 & $24-25$ & AIOM & Poz-121675 & 20,530 & 150 & 3400 & 17,130 & 19,233 & 18,796 & 19,683 \\
\hline KI-13 BC04 & $36-37$ & AIOM & 4806.1.1 & 22,810 & 419 & 3400 & 19,410 & 22,005 & & \\
\hline
\end{tabular}

a AIOM: acid-insoluble organic matter; N. pachy: monospecific planktic tests. ${ }^{\mathrm{b}}$ LCO: local contamination offset; see text for explanation. 
Taking into consideration the different carbonate and organic carbon matrices, we decided to directly calibrate the carbonate dates and to treat AIOM dates prior to the calibration in ${ }^{14} \mathrm{C}$ ages. Radiocarbon chronologies using the AIOM fraction from bulk sediments are often compromised by contamination from the reworked old organic carbon derived from glacial erosion and/or from the reworking of unconsolidated sediments (see $[30,31]$ for the discussion). This is evidenced by AIOM dates of Antarctic surface sediments that extend over several thousand years $[32,33]$. The AIOM dates of the surface levels $(0-1 \mathrm{~cm})$ of $\mathrm{BC} 02$ and $\mathrm{BC} 04$ have been used to correct the respective ages in depth for each box-core. These surficial dates embed the regional marine reservoir effect (MRE) and the local dead carbon contamination offset (LCO), assuming that both MRE and LCO did not change during the Holocene ([29,30] for details). We also assumed that the age difference between the AIOM ${ }^{14} \mathrm{C}$ age of the core-top of two box cores and the Marine Reservoir Effect (MRE) represents the local contamination with older organic matter in this area, and hereafter it is referred to as LCO (see discussion in [34]). Before calibrating the ${ }^{14} \mathrm{C}$ dates, the LCO obtained for this area was subtracted from the AIOM ${ }^{14} \mathrm{C}$ down box-cores ages (LCO corrected ages), assuming that both MRE and LCO did not change over the Holocene ([29,30] for details). We used a MRE of $1.1 \pm 0.12 \mathrm{ka}{ }^{14} \mathrm{C}$ suggested by [29] for the Ross Sea carbonate samples as the box-core BC03 was only dated in two subsurface levels using carbonates (Table 2), the surface level is assumed to be of modern age, similar to the other two box cores.

The LCO corrected AMS ${ }^{14} \mathrm{C}$ dates performed on AIOM and those performed on N. pachyderma tests were converted into calibrated ages by means of the CALIB REV 7.1 calibration program [27], at 95\% confidence ranges. The MARINE 13 calibration curve [28], assuming regional marine offset $(\Delta \mathrm{R}) 0.79 \pm 0.12 \mathrm{ka}$ from the global MRE [29], was used. The new calibration curve (MARINE 20, [35]) was not used since it is not suitable for the calibration of Antarctic sediments, as suggested by [36].

\subsection{Grain Size Analyses}

Grain sizes analyses were performed on 1-cm thick subsamples at 1-2-cm intervals. The fraction $>1 \mathrm{~mm}$ was separated by sieving to remove the larger grains. Grains were counted as belonging to the same sediment aliquot, and were thus used as an indicator of the coarse detrital component as a whole. The grain size characterisation of the $<1 \mathrm{~mm}$ fraction was carried out using a Malvern Mastersizer Hydro2000S diffraction laser unit. Sand, silt, and clay fractions were determined using the grain-size classification proposed by [37]. Statistical parameters (mean size Mz, sorting oi, skewness Sk, kurtosis Kg) were determined according to [38]. We did not remove the biogenic silica fraction due to the abundance of siliciclastic particles highlighted during smear slide analyses as suggested by [39]. Moreover, the presence of non-biogenic amorphous silica resulting from volcanic glass or as an output from glacial abrasion should be considered part of the sediment archive. The parameters sortable silt mean size (mean SS) and percentage (SS\%) were calculated from the grain size dataset according to [40]. Half-PHI $(\Phi)$ grain size data were used for clustering through the non-hierarchical K-means method. The number of iterations was stopped at $n=6$, e.g., when achieving a number of grain-size end-members (=clusters) representative of the regular fining/coarsening of the grain-size spectra or the uni- or bi-pluri-modal feature of the distribution. Elaboration was carried out using the Past3 open-source program (version 3.18, [41]).

\subsection{Cryptotephra Analyses}

A cryptotephra, i.e., a layer of volcanic ash not visible at the naked eye, was identified during the micropaleontological investigation at 38-39 cm of sediment depth in BC04. The bulk sediment sample was treated using $\mathrm{H}_{2} \mathrm{O}_{2}$ with $40 \%$ concentration to dissolve organic matter, washed with deionized water in an ultrasonic bath and dried at $60{ }^{\circ} \mathrm{C}$. The treated sample was then impregnated in epoxy resin, polished and prepared for textural and geochemical (major and minor elements) analyses. The textures and composition of 
glass particles in the BC04 38-39 sample were studied using a scanning electron microscope (SEM), Zeiss EVO MA coupled with an Oxford-Aztec Energy EDS Analysis System. Standards of volcanic glass (VG2) were analysed for comparison. Cryptotephra analyses were performed at the Institution of Geophysics and Volcanology (INGV) Pisa Lab.

\subsection{Micropaleontological Analyses}

\subsubsection{Diatoms}

A total of 64 samples were performed according to the methodology described in [42]. A diatom count was performed under a microscope at a magnification of $1000 \times$. For each sample, at least 300 diatom valves were counted for each slide following the counting rules proposed by [43] and taxonomical identification is based on [44]. When the diatom concentration was too low, five hundred fields of view per slide were analysed. The total absolute diatom abundance (ADA) in terms of the number of frustules per gram of dry weight $(\mathrm{v} / \mathrm{gdw})$, was calculated using the formula described by [45]. The relative abundance (expressed in \%) in each sample was also calculated as the ratio between the diatom species and the total diatom abundance. Relative percentage of each diatom species was estimated as a percentage of the Chaetoceros resting spore free diatom assemblage (e.g., [46]). Species occurring at $<2 \%$ were considered as statistically not significant [47].

\subsubsection{Silicoflagellates}

Silicoflagellates were counted from 69 samples on the same slides prepared for diatoms. Counts were performed at $200 \times$ magnification with an Olympus BX50 light microscope. Up to 60 specimens of Stephanocha speculum were counted in each sample, to calculate the Absolute Silicoflagellate Abundance (ASA) in terms of silicoflagellates per gram of dry weight (s/gdw) following the same formula used for diatoms. Depending on silicoflagellate density, a slide surface of $8-250 \mathrm{~mm}^{2}$ was scanned, resulting in a detectability limit of $0.5-1 \times 10^{4} \mathrm{~s} / \mathrm{gdw}$. Each S. speculum specimen was observed at $1000 \times$ with immersion oil for morphotype identification, following the taxonomic concepts of [48] and recent review of [49]. Morphotypes were grouped according to their ecological preferences [50] and percent values were calculated only when silicoflagellate density was statistically significant.

\subsubsection{Foraminifera}

A total of 28 samples were collected to study the planktic and benthic foraminiferal assemblage. The samples were washed through a $63-\mu \mathrm{m}$ sieve; foraminifera were studied in the sediment fraction $>63 \mu \mathrm{m}$, using a binocular microscope. When the foraminifera were abundant, the samples were subdivided using a dry splitter until an aliquot containing approximately 300 specimens was obtained. The species counts were carried out only on well-preserved specimens and recorded as the number of specimens of each taxon; these data were subsequently converted into frequency expressed as a percentage and as densities (the number of specimens/g of total sediment). The number of broken and/or etched foraminifera allowed us to calculate the $\%$ of fragmentation for each level. All foraminifera were identified at species levels, except for Lagena and Oolina which were identified at the generic level. The identification mainly follows [51-54]. The online catalogue [55] was used to consult original taxa descriptions.

\section{Results}

\subsection{Box Core Description}

BC02 (Figure 2) consists of $37 \mathrm{~cm}$ of soupy and sticky structureless olive (5Y 5/4) silt to sandy silt sediments. X-rays reveal abundant gravel content more concentrated at the base and at the top of the box. BC03 (Figure 2) is composed of $37 \mathrm{~cm}$ of soft and hydrated olive (5y 4/4) silty sand to sandy silt sediments with abundant pebbles more concentrated at the base of the box corer. X-rays reveal that the pebbles are iso-oriented at around $30 \mathrm{~cm}$. A weak bioturbation is present. BC04 (Figure 2) consists of $45 \mathrm{~cm}$ of olive (5y 4/4) sticky 
structureless sandy silt to silt with sparse pebbles more concentrated at the top and bottom of the box.

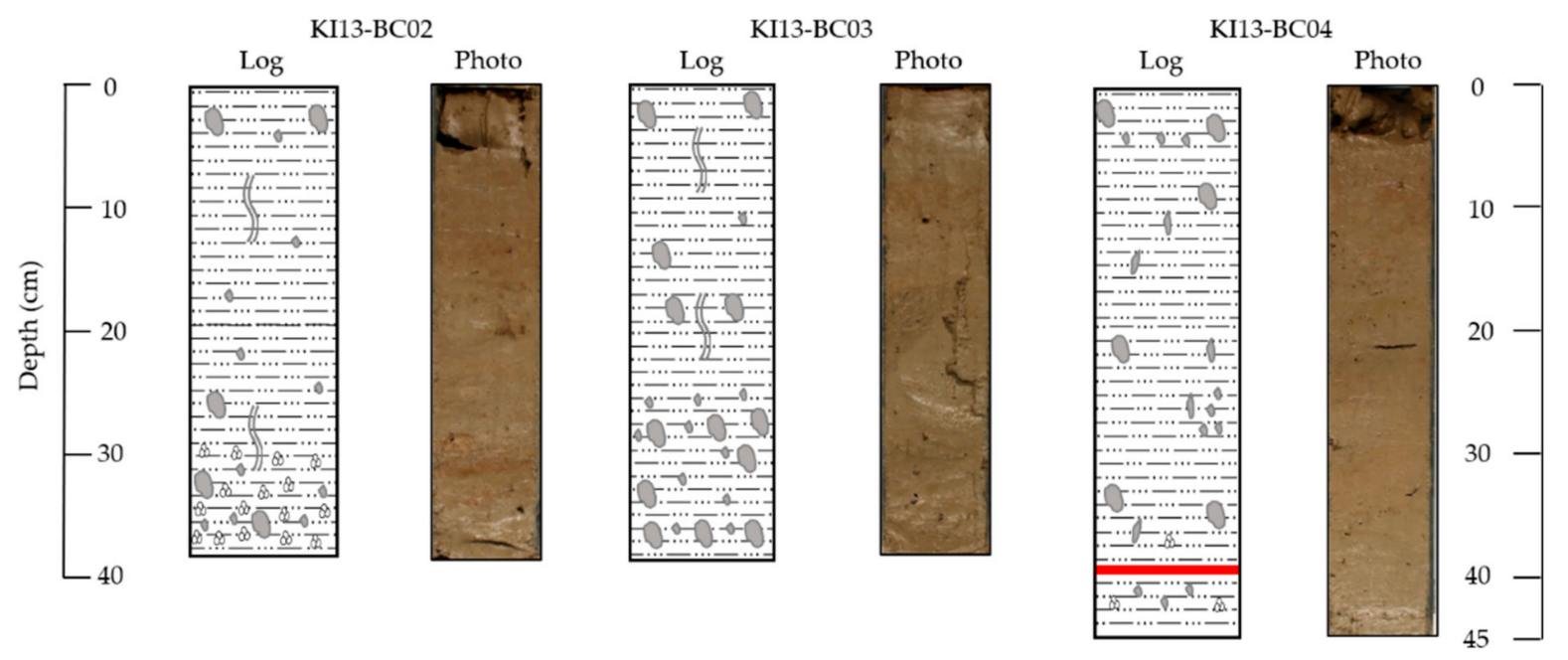

Legend:

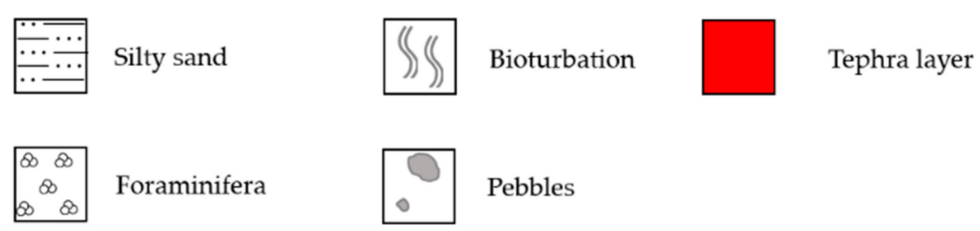

Figure 2. Sedimentological log and photo of three box cores.

\subsection{Age Model}

The chronological reconstruction based on the calibrated ages corresponds to time intervals spanning from $24 \mathrm{ka}$ BP to the late Holocene. The age-depth model was calculated using a linear interpolation function between dated levels (Figure 3).

KI-13 BC02

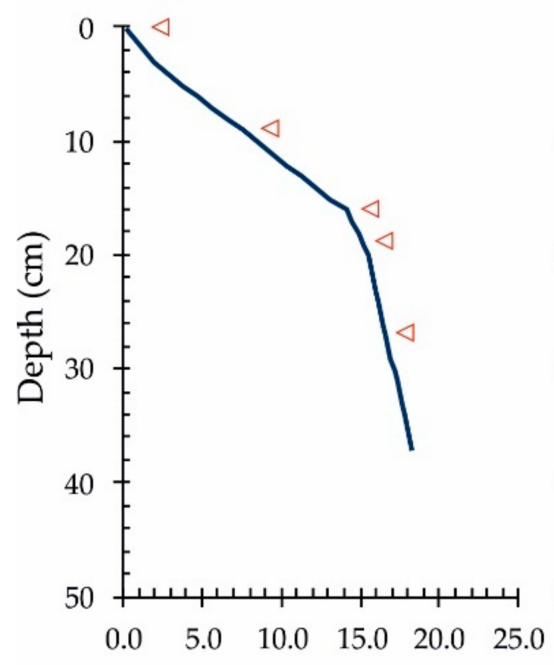

Age (cal ka BP)
KI-13 BC03

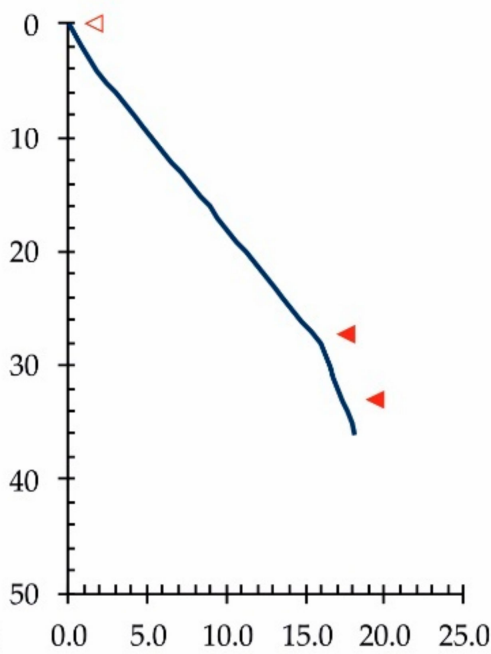

Age (cal ka BP)

\section{KI-13 BC04}

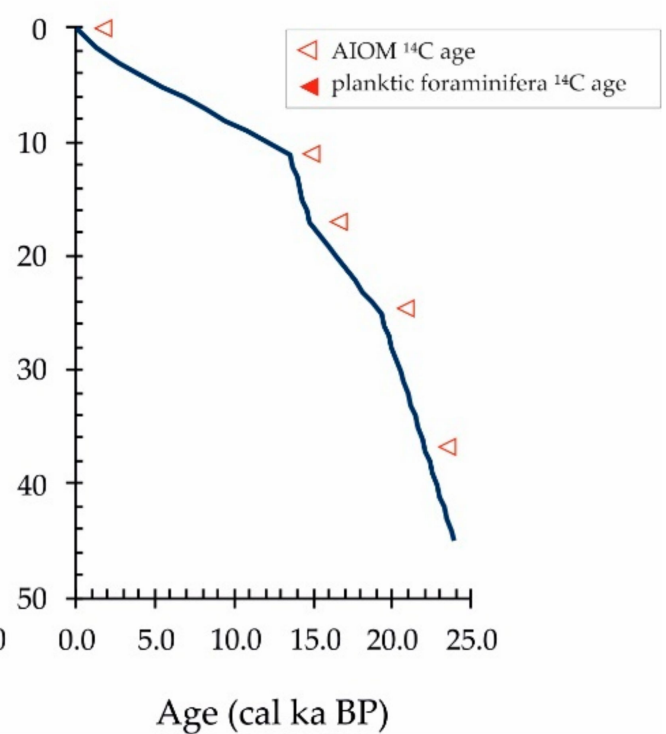

Figure 3. Age-depth model based on the linear interpolation of best point calibration ages from AMS. 
Sedimentation rates are variable among the box cores (Figure 3). As a general rule, the box cores show the highest sedimentation rates (from 3.62 to $5.99 \mathrm{~cm} / \mathrm{ky}$, without considering a temporary drop in BC 04) for the levels approximately older than $15 \mathrm{ka}$ $\mathrm{BP}$, whereas the lowest sedimentation rates (from 0.74 to $1.70 \mathrm{~cm} / \mathrm{ky}$ ) characterise the entire Holocene.

\subsection{Sediment Grain Size}

The raw grain-size data are reported in Table S1 and the grain size box core detailed description can be found in Supplementary S1.

The statistical approach allows for the grouping of samples in six clusters (Table S1) with a marked similarity of two pairs of clusters (2 and 3, as well as 4 and 5). Mean grain size distributions are represented in Figure 4 and the main statistical parameters of each cluster are summarised in Table 3. The continuum given by the sequence of clusters from one to five represents the progressive increase in sand and sortable silt (sensu Mc Cave et al. [40]), both in terms of proportion to the entire $<63 \mu \mathrm{m}$ fraction (SS\%) and the mean SS size. Accordingly, the central tendency parameters (mean and median) also increase from cluster 1 to 5 , representative of a clear shifting of the primary mode of the grain size distribution of each cluster (see Figure 4), from $10 \mu \mathrm{m}$ (cluster 1), $20 \mu \mathrm{m}$ (cluster 2), $30 \mu \mathrm{m}$ (cluster 3), $35 \mu \mathrm{m}$ (cluster 4), to $40 \mu \mathrm{m}$ (cluster 5). Cluster 6 represents a separate group of samples with the coarsest mode $(55 \mu \mathrm{m})$ and a poorly sorted distribution, markedly asymmetrical.

Table 3. Main grain size data and statistical parameters for each grain size cluster. $\mathrm{Mz}, \sigma_{\mathrm{i}}, \mathrm{Sk}$ and $\mathrm{Kg}$ are the mean size, sorting, skewness and kurtosis according to [38], C is the 1st percentile, M is the median, SS is the sortable silt, calculated according to [40].

\begin{tabular}{|c|c|c|c|c|c|c|c|c|c|c|c|c|c|}
\hline & & Sand & Silt & Clay & Mz & $\sigma_{\mathrm{i}}$ & Sk & $\mathrm{Kg}$ & $\mathrm{C}$ & $\mathbf{M}$ & $>1 \mathrm{~mm}$ & SS $\%$ & SSmean \\
\hline & & $\%$ & $\%$ & $\%$ & $\Phi$ & $\Phi$ & & & $\mu \mathrm{m}$ & $\mu \mathrm{m}$ & counts & & $\mu \mathrm{m}$ \\
\hline \multirow{2}{*}{ CLUSTER 1} & avg & 11.1 & 81.5 & 7.4 & 6.25 & 1.90 & -0.01 & 1.10 & 445 & 13 & 36 & 53.5 & 22.2 \\
\hline & SD & 3.2 & 3.7 & 0.9 & 0.15 & 0.18 & 0.07 & 0.08 & 84 & 2 & 16 & 3.5 & 0.8 \\
\hline \multirow{2}{*}{ CLUSTER 2} & avg & 11.2 & 82.2 & 6.6 & 5.99 & 1.80 & 0.14 & 1.01 & 351 & 17 & 25 & 61.9 & 24.5 \\
\hline & SD & 2.2 & 2.2 & 0.9 & 0.11 & 0.08 & 0.05 & 0.05 & 123 & 1 & 26 & 2.1 & 0.6 \\
\hline \multirow{2}{*}{ CLUSTER 3} & avg & 16.6 & 77.2 & 6.2 & 5.71 & 1.89 & 0.17 & 1.02 & 428 & 22 & 25 & 64.8 & 26.1 \\
\hline & SD & 3.7 & 3.5 & 0.5 & 0.14 & 0.11 & 0.06 & 0.06 & 87 & 2 & 23 & 1.9 & 0.5 \\
\hline \multirow{2}{*}{ CLUSTER 4} & avg & 19.8 & 75.4 & 4.8 & 5.40 & 1.82 & 0.20 & 1.13 & 450 & 28 & 34 & 71.3 & 27.7 \\
\hline & SD & 3.6 & 3.5 & 0.5 & 0.14 & 0.13 & 0.05 & 0.06 & 72 & 3 & 18 & 2.1 & 0.5 \\
\hline \multirow{2}{*}{ CLUSTER 5} & avg & 27.4 & 68.9 & 3.7 & 4.98 & 1.77 & 0.20 & 1.30 & 472 & 37 & 61 & 77.0 & 30.1 \\
\hline & SD & 2.0 & 2.0 & 0.2 & 0.09 & 0.12 & 0.05 & 0.07 & 52 & 2 & 9 & 2.2 & 0.9 \\
\hline \multirow[b]{2}{*}{ CLUSTER 6} & avg & 31.3 & 63.7 & 5.0 & 5.14 & 2.05 & 0.19 & 0.99 & 493 & 34 & 48 & 65.7 & 27.5 \\
\hline & SD & 5.2 & 4.6 & 0.8 & 0.25 & 0.16 & 0.10 & 0.06 & 88 & 7 & 41 & 3.4 & 1.4 \\
\hline
\end{tabular}

In order to extrapolate information on selective processes responsible for the different grain size patterns, we tested the sortable silt signal through the classical SS\% vs. mean SS relationship ([39] and references therein). Data are grouped according to the extracted clusters and reported as a whole dataset and in separate relationships, one for each core (Figure 5). Linear correlations are significant in all cases; data are very highly correlated both for the whole dataset $(r=0.89)$ and for each core, corresponding to $r=0.93$ for BC02, $\mathrm{r}=0.89$ for $\mathrm{BC} 03$ and $\mathrm{r}=0.88$ for BC04. 

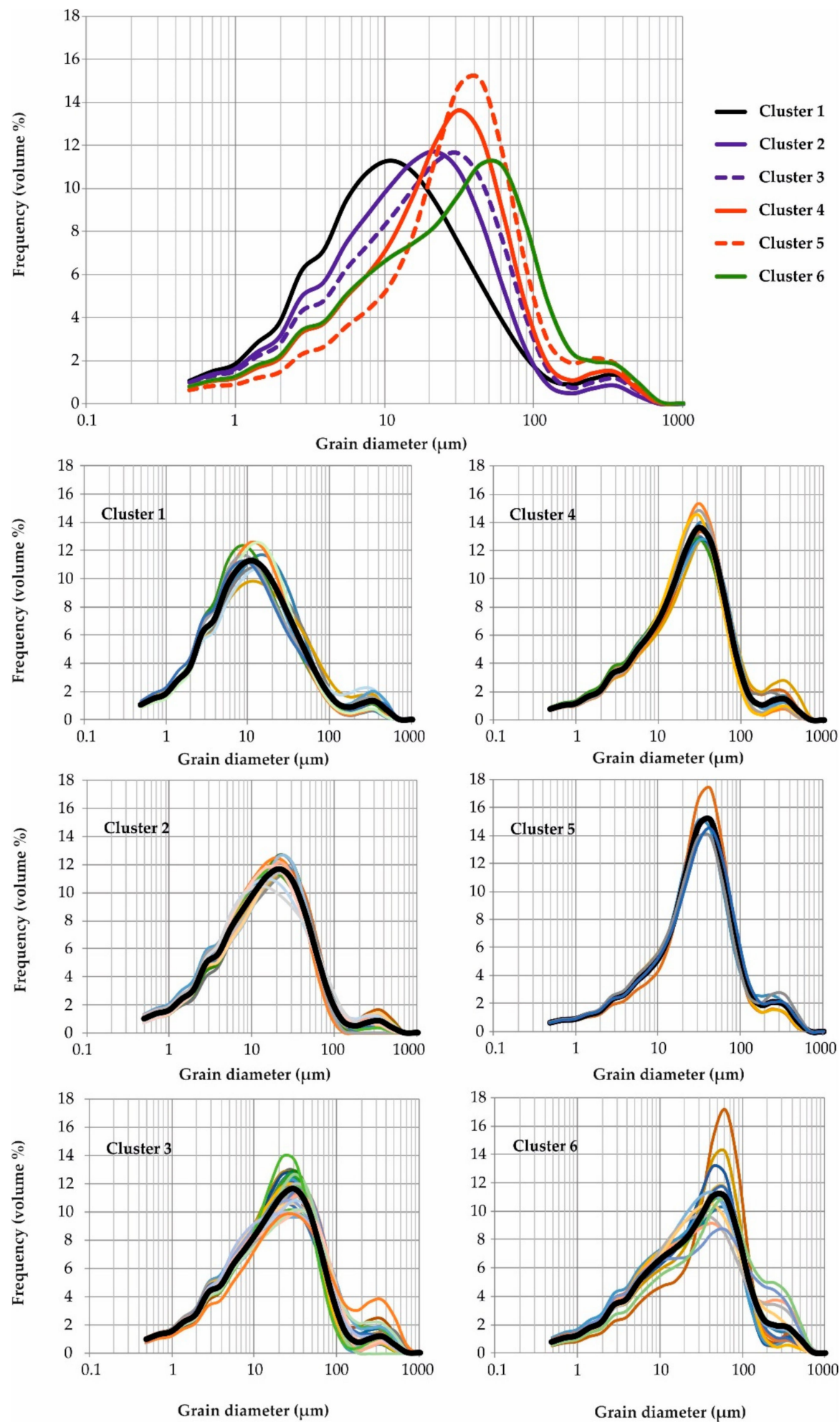

Figure 4. Mean grain size distributions of the six extracted clusters (upper plot). The lower plots report the details of the grain size distribution of each cluster, from the finest mode (cluster 1) to the coarsest mode (cluster 6). The black lines represent the mean grain size curves.

The grain size trend along the three box cores is represented by the vertical distribution of the clusters, (Figure 6). In the same graph the number of dropstones (fraction $>1 \mathrm{~mm}$ ) recovered in the fixed amount of sediment used for the grain size analysis is used as a proxy of the vertical flux linked to the Ice Rafted Debris (IRD). BC02 and BC03 show a 
similar fining and subsequent coarsening trend downcore, although not represented by the same cluster sequence. BC04 is texturally quite homogenous, after a coarser 9-cm thick topmost layer (cluster 5 and 4). BC02 and BC04 feature a significant amount of IRD, either at the base of both cores and at the already defined topmost layer of the latter core.

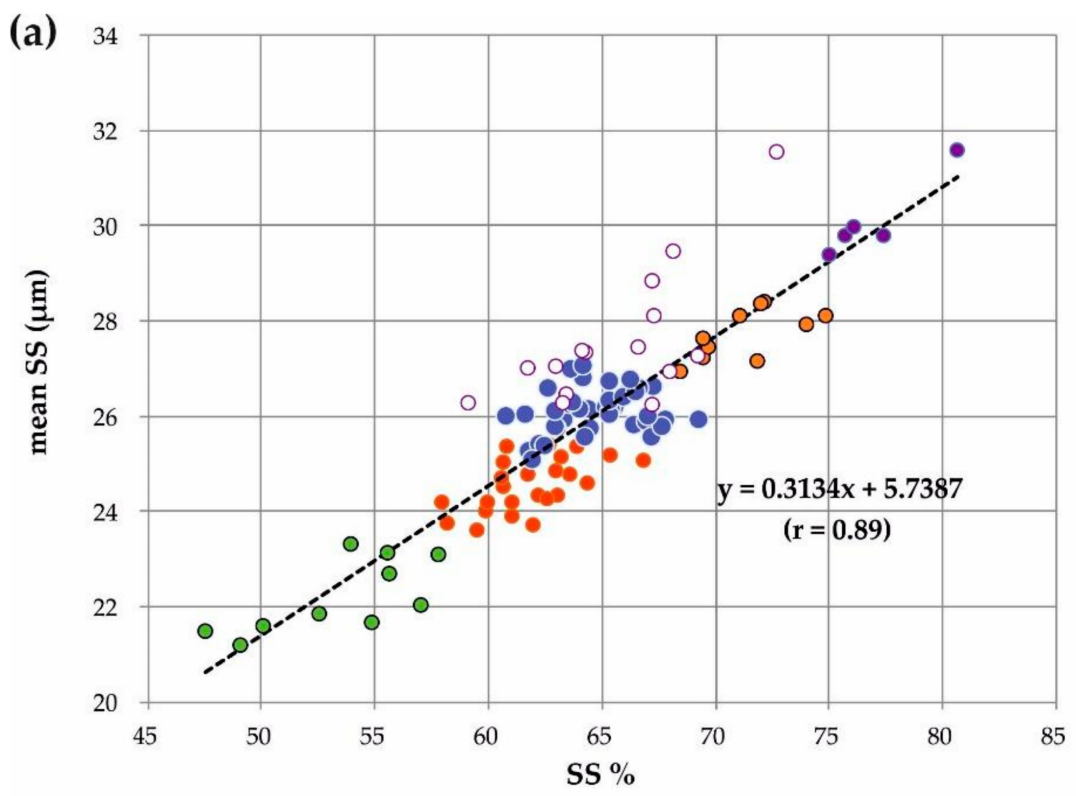

- Cluster 1

- Cluster 2

- Cluster 3

- Cluster 4

- Cluster 5

o Cluster 6
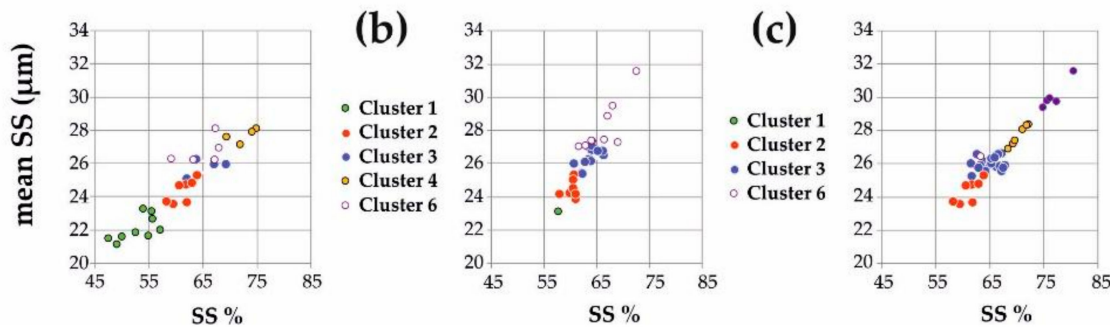

(d)

- Cluster 2

- Cluster 3

- Cluster 5

- Cluster 6

Figure 5. Relationship between mean SS and SS\% for (a) the whole sediment dataset, (b) core BC02, (c) core BC03, and (d) core BC04, according to the different clusters.
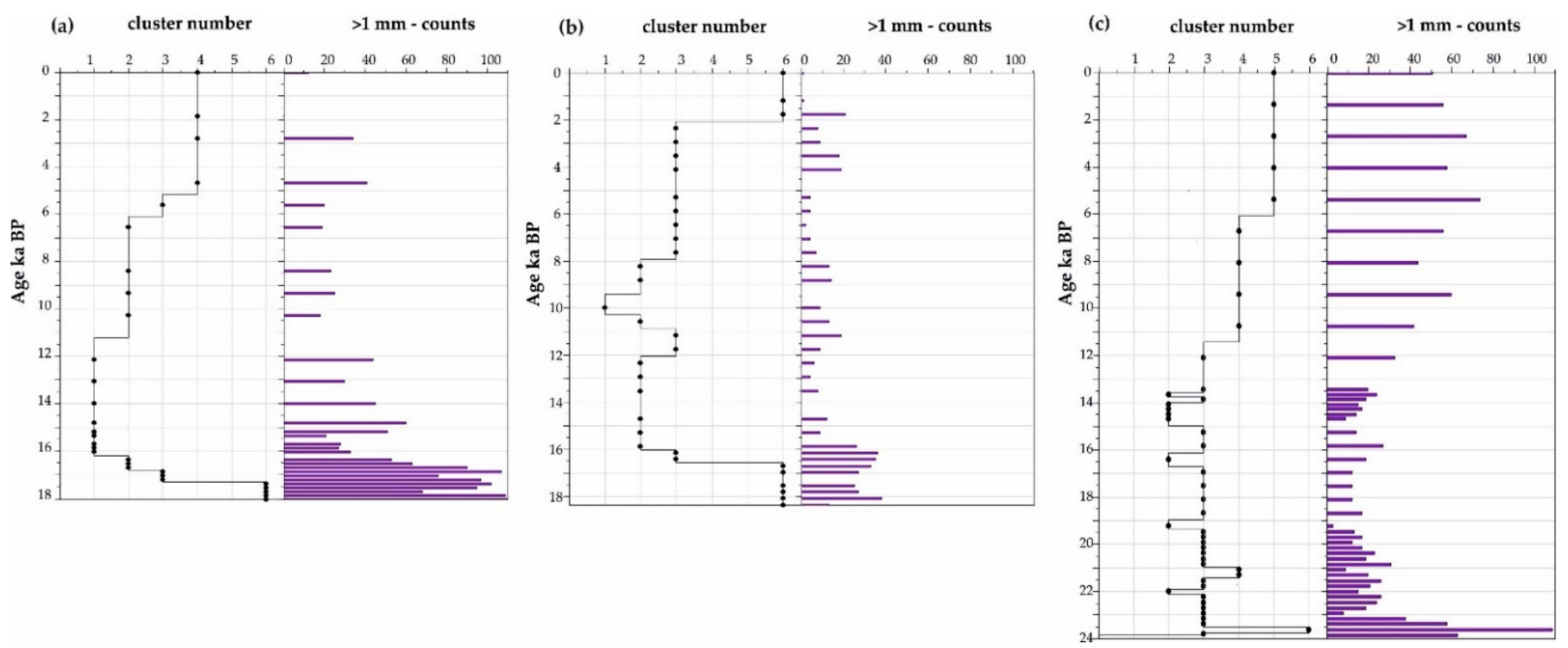

Figure 6. Down-core distribution of the grain size clusters and >1-mm fraction: (a) BC02 (b) BC03 (c) BC04. 


\subsection{Cryptotephra Textures and Glass Chemistry}

BC04 38-39 cryptotephra is made of glass shards and micropumices set in a matrix made of biogenic (mainly diatoms) and detritic (crystals of quartz and feldspar, granitoids rock fragments, etc.) grains (>32 micron). BC04 38-39 cryptotephra consists of colourless glass shards up to $60-70 \mu \mathrm{m}$ and micropumices up to $120 \mu \mathrm{m}$, respectively, showing pristine morphologies. Micropumices are poorly to moderately vesicular, frothy vesicular to tubular and glass shards comprising blocky, y-shaped to platy-shaped fragments dense to poorly vesicular (Figure 7a,b) [56-61]. Glasses of BC04 38-39 tephra show dominant phonolite compositions with minor trachyte $\left(57.8-61.1 \mathrm{wt} \% \mathrm{SiO}_{2} ; 12.3-15.9 \mathrm{wt} \% \mathrm{Na}_{2} \mathrm{O}+\mathrm{K}_{2} \mathrm{O}\right.$; (Figure 7c,d) [56-61]. The main compositional variability can be ascribed to the $\mathrm{Na}_{2} \mathrm{O}$ that decreases with increasing $\mathrm{SiO}_{2}$, whereas $\mathrm{FeO}_{\text {tot }}(5.9-7.8 \mathrm{wt} \%), \mathrm{Al}_{2} \mathrm{O}_{3}(16.2-18.1 \mathrm{wt} \%), \mathrm{K}_{2} \mathrm{O}$ $(4.8-5.1 \mathrm{wt} \%)$, and $\mathrm{CaO}(0.9-1.6 \mathrm{wt} \%)$ contents seem unrelated with $\mathrm{SiO}_{2}$ variation.
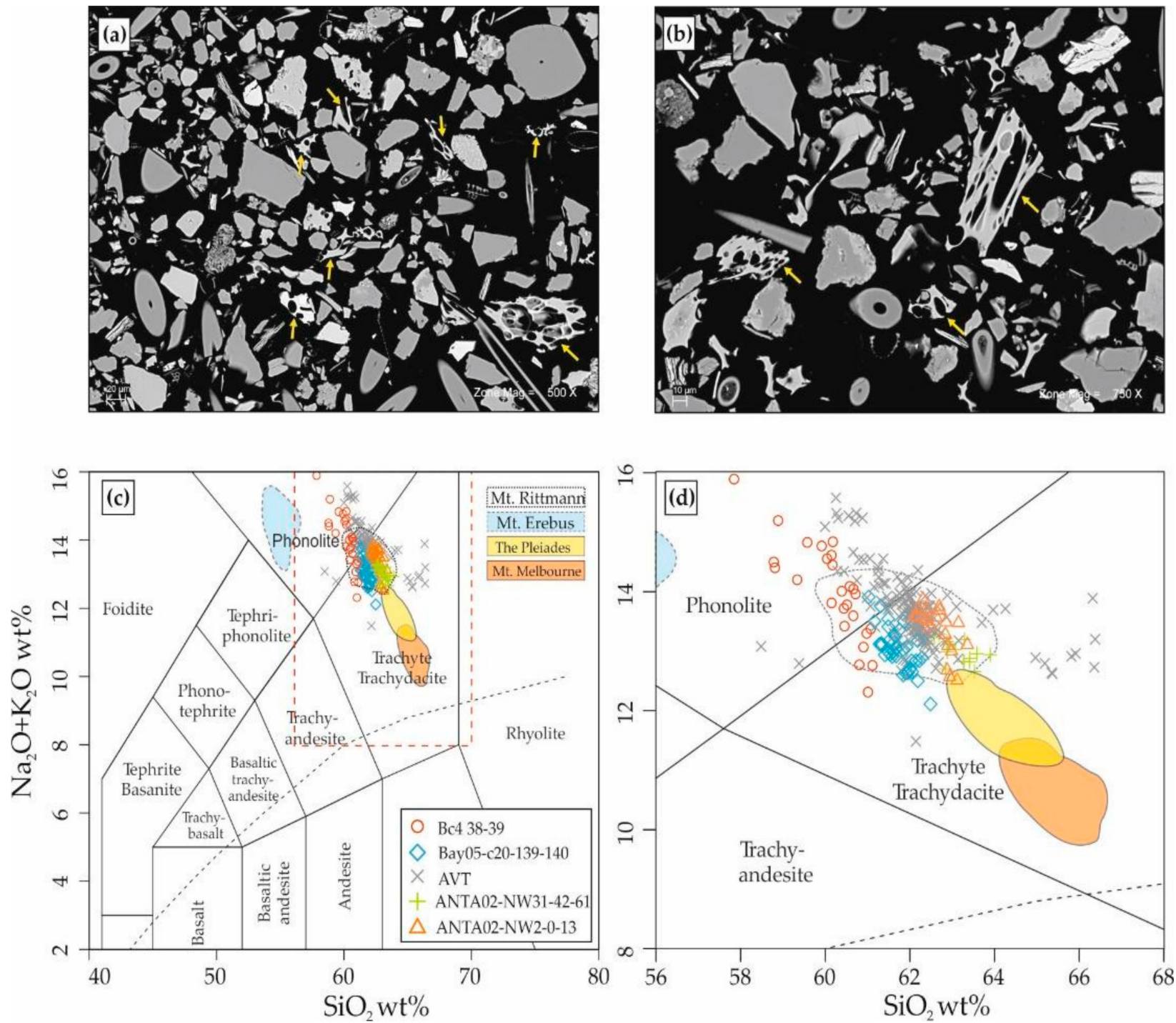

Figure 7. (a,b) SEM backscatter images of glass particles forming the BC4 38-39 crytotephra; (c,d) Total Alkali Silica (TAS; [56]) classification diagram showing individual glass shard composition in the BC4 38-39 cryptotephra and compared with available analyses of tephra and cryptotephra in the literature from other volcanic centres (Mount Rittmann: [57,58]; The Pleiades: [58]; Mount Melbourne: [58]; Erebus volcano: [59]). Bay05: [58]; AVT: [60]; ANTA02-NW2 and -NW31: [60]. 


\subsection{Micropaleontological Contents}

\subsubsection{Diatom Assemblage}

The diatoms are well preserved and do not show dissolution features represented by the loss of valve margin, the breakage of the middle part, distorted or/and conjoined pores on diatom valves, and the breakage of areolae, etc. This is also confirmed, in agreement with [43], by the higher presence of Fragilariopsis kerguelensis then Thalassiosira lentiginosa. The ecological significance of different taxa can be found in Supplementary S2.

Total absolute diatom abundance (ADA) in BC02 varies between 5.5 and $120.6 \times 10^{6}$ valves per gram of dry sediment (v/gds), in BC03 from 9.7 to $199.1 \times 10^{6}(\mathrm{v} / \mathrm{gds})$ and in BC04 from 4.2 to $218.4 \times 10^{6}(\mathrm{v} / \mathrm{gdw})$. The diatom record shows low abundance before to $31 \mathrm{~cm}$ in $\mathrm{BC} 02,29 \mathrm{~cm}$ in $\mathrm{BC} 03$, and $21 \mathrm{~cm}$ in $\mathrm{BC} 04$ (ca. $17 \mathrm{ka} \mathrm{BP}$ ), followed by a rapid increase and then at about $14 \mathrm{~cm}$ in BC02, $10 \mathrm{~cm}$ in BC03 and $10 \mathrm{~cm}$ in BC04 (12 ka BP for $\mathrm{BC} 02$ and $\mathrm{BC} 04 ; 9 \mathrm{ka} \mathrm{BP}$ for $\mathrm{BC} 03) \mathrm{ka} \mathrm{BP}$ ADA decreases towards the core-top.

A total of 56 diatom species are identified; the following species mainly characterise the diatom assemblage: Actinocyclus actinochilus, Eucampia antarctica, Fragilariopsis curta, F. obliquecostata, F. kerguelensis, Thalassiosira antarctica, T. lentiginosa, T. oliverana, and Chaetoceros hyalochaete resting spores (CRS). CRS dominate the diatoms assemblage (avg. 30-33\%) of all box-cores.

In BC02 (Figure 8), F. kerguelensis (avg. 22\%) has a positive trend from the core-bottom of the core to $30 \mathrm{~cm}$ and then it becomes the dominant species from $30 \mathrm{~cm}$ to $8 \mathrm{~cm}(17 \mathrm{ka}$ $\mathrm{BP}$ to $6.5 \mathrm{ka} \mathrm{BP}$ ), and then it decreases towards the core-top. Relative abundances of E. antarctica (avg. 17\%) present the downcore opposite trend to the one of F. kerguelensis over the entire record. Relative abundances of E. antarctica are the highest between the core-bottom and $30 \mathrm{~cm}$ (18-17 ka BP) and from $12 \mathrm{~cm}$ (10.2 ka BP) to the core-top of the core. Fragilariopsis obliquecostata (avg. 18\%) presents a higher value until $27 \mathrm{~cm}(16.5 \mathrm{ka} \mathrm{BP})$, then decreases until $11 \mathrm{~cm}(9 \mathrm{ka} \mathrm{BP})$. From $11 \mathrm{~cm}$ to $2 \mathrm{~cm}$ (9 ka BP to $1 \mathrm{ka} \mathrm{BP)} \mathrm{F.} \mathrm{obliquecostata}$ slightly increases and subsequently decreases. Fragilariopsis curta (avg. 13\%) increases from the core-bottom to $19 \mathrm{~cm}(18-15 \mathrm{ka} \mathrm{BP})$, and then decreases until $12 \mathrm{~cm}(10.2 \mathrm{ka} \mathrm{BP})$, and it increases again from $12 \mathrm{~cm}$ to the core-top (10.2 ka BP-present). The "warm water group", represented by the sum of Thalassiosira lentiginosa, T. oliverana, and T. gracilis (avg. $4 \%)$, presents a very low relative abundance, increasing towards the core-top. Actinocyclus actinochilius (avg. $4 \%$ ) presents the highest value from the core-bottom to $30 \mathrm{~cm}(18-17 \mathrm{ka}$ BP). Paralia sulcata (avg. 2\%) increases from $12 \mathrm{~cm}$ to the core-top (10 ka BP to present) with the highest value at the top.

In BC03 (Figure 9), F. kerguelensis (avg. 19\%), increased from $33 \mathrm{~cm} \mathrm{(17.2} \mathrm{ka} \mathrm{BP),}$ becoming the dominant species from $29 \mathrm{~cm}$ to $10 \mathrm{~cm}$ (17 ka BP to $6.5 \mathrm{ka} \mathrm{BP}$ ). F. curta (avg. $18 \%$ ) presents a constant trend from $17 \mathrm{~cm}$ to $8 \mathrm{~cm}$ (14-6.5 ka BP), then increases until $5 \mathrm{~cm}(4 \mathrm{ka} \mathrm{BP})$ and decreases towards the core-top. Relative percentages of E. antarctica (avg. 15\%) then decrease from the core-bottom to $17 \mathrm{~cm}$ (18-9.4 ka BP) than increase towards the core-top. F. obliquecostata (avg. 12\%) has the highest value at the bottom (18 ka $\mathrm{BP})$ and at $2 \mathrm{~cm}(1 \mathrm{ka} \mathrm{BP})$. From $33 \mathrm{~cm}$ to $8 \mathrm{~cm}(17-6.5 \mathrm{ka} \mathrm{BP})$ it presents a lower value, subsequently increasing until $2 \mathrm{~cm}(1 \mathrm{ka} \mathrm{BP})$. The "warm water group" (avg. $2 \%$ ) presents low abundances and increases from $5 \mathrm{~cm}(3.8 \mathrm{ka} \mathrm{BP})$ to the core-top. P. sulcata is present from $8 \mathrm{~cm}(6.5 \mathrm{ka} \mathrm{BP})$. 


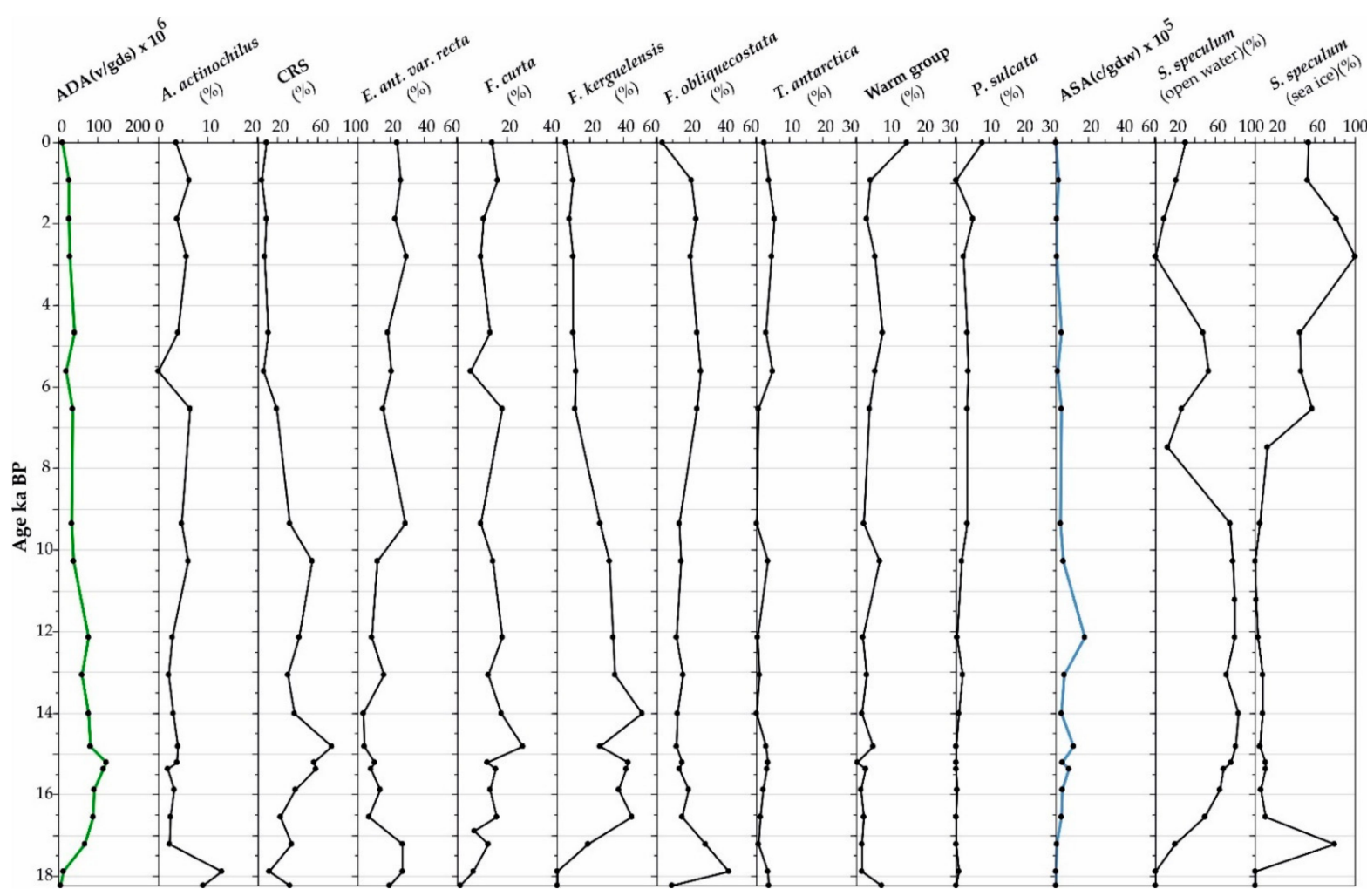

Figure 8. Down-core distribution of diatom and silicoflagellate present in BC02. The variety S. speculum var. monospicata and var. bispicata, with var. speculum, represent the open ocean, while S. speculum var. coronata represents the marginal ice zone and the Ross Sea coastal areas.

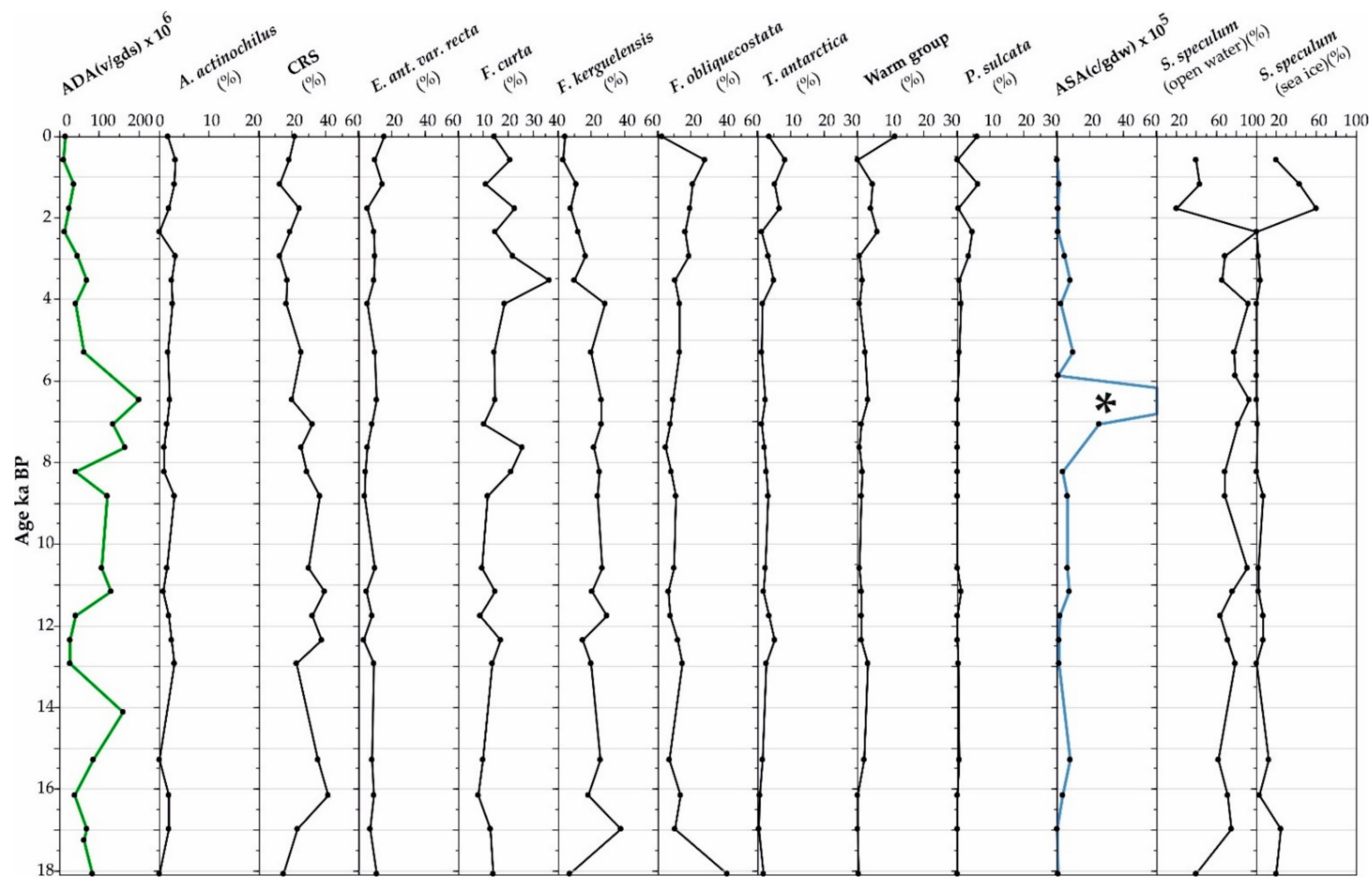

Figure 9. Down-core distribution of diatom and silicoflagellate present in BC03. The variety S. speculum var. monospicata and var. bispicata, with var. speculum, represent the open ocean, while S. speculum var. coronata represents the marginal ice zone and the Ross Sea coastal areas. The asterisk indicates values out of scale $\left(112.23 \mathrm{c} / \mathrm{gdw} \times 10^{5}\right)$. 
In BC04 (Figure 10), F. obliquecostata (avg. 17\%) increases from the core-bottom to $19 \mathrm{~cm}$ (24-16 ka BP), and then decreases towards the core-top. E. antarctica (avg. 14\%) presents high percentage values from the core-bottom to $14 \mathrm{~cm}(24-14 \mathrm{ka} \mathrm{BP})$, then decreases towards the core-top. Similar to BC02 and BC03, F. kerguelensis (avg. 13\%) increases from $19 \mathrm{~cm}$ (16 ka BP) and presents high values to the entire downcore trend. F. curta (avg. 11\%) presents a constant trend until $21 \mathrm{~cm}(17 \mathrm{ka} \mathrm{BP})$, and then slightly increases until $7 \mathrm{ka}$ BP, and subsequently decreases from $7 \mathrm{ka} \mathrm{BP}$ to the core-top. In BC04, T. antarctica (avg. 5\%) is present from the core-bottom to $21 \mathrm{~cm}$ (24 ka BP to $17 \mathrm{ka} \mathrm{BP})$. The "warm water group" (avg. 3\%) presents a low value and increases from $4 \mathrm{~cm}$ to the core-top (4 ka BP-present). In contrast, from BC02 and BC03, P. sulcata in BC04 reaches the maximum abundances increase from $4 \mathrm{~cm}$ to the core-top ( $4 \mathrm{ka} \mathrm{BP}$-present).
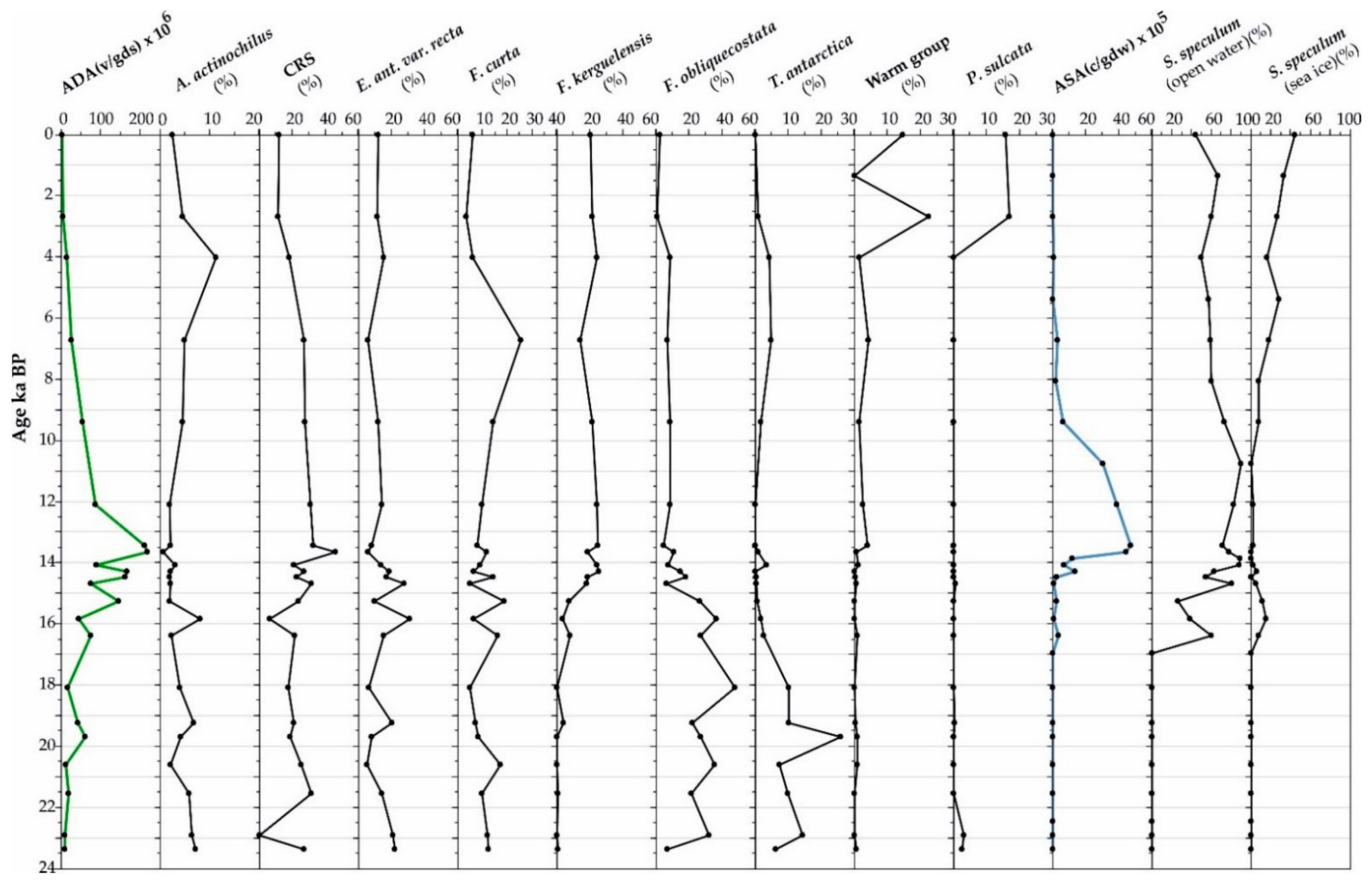

Figure 10. Down-core distribution of diatom and silicoflagellate present in BC04. The variety S. speculum var. monospicata and var. bispicata, with var. speculum, represent the open ocean, while S. speculum var. coronata represents the marginal ice zone and the Ross Sea coastal areas.

\subsubsection{Silicoflagellates}

Silicoflagellates are represented by only one species, Stephanocha speculum (see Supplementary S2), which shows good preservation in all samples (Figures 8-10). Silicoflagellates are scarce before $33 \mathrm{~cm}$ in BC2 and $23 \mathrm{~cm}$ in BC04 (ca. $18 \mathrm{ka} \mathrm{BP}$ ), then increase in abundance with ASA values of $6.0 \times 10^{4}-1.6 \times 10^{6}$ skeletons $/ \mathrm{gdw}$ in BC02, $4.9 \times 10^{4}-11.0 \times 10^{6}$ in $\mathrm{BC} 03$, and $0.6 \times 10^{4}-4.7 \times 10^{6}$ in BC04, and then decrease towards the core-top of all the box-cores.

Within S. speculum, the most abundant varieties are var. speculum, var. monospicata, and var. coronata, grouped together as the open ocean varieties. Among these varieties, rare forms with pentagonal/heptagonal outline or with a large apical ring are included. In BC02 (Figure 7), the cumulative abundance of the open ocean varieties is above $50 \%$ 
between 27 and $11 \mathrm{~cm}$ (16.5 and $9 \mathrm{ka} \mathrm{BP})$, then drops at 9-8 $\mathrm{cm}(7.5-6.5 \mathrm{ka} \mathrm{BP})$, increases again to $\sim 50 \%$ at $7-6 \mathrm{~cm}(5.6-4.6 \mathrm{ka} \mathrm{BP})$, and then decreases to values below $21 \%$ in the upper $4 \mathrm{~cm}$ (latest $2.8 \mathrm{ka} \mathrm{BP}$ ); in BC03 (Figure 8) it is above $60 \%$ from 32 to $5 \mathrm{~cm}$ (17 to $2.3 \mathrm{ka}$ $\mathrm{BP})$, then decreases to lower values in the upper $4 \mathrm{~cm}$ (latest $1.7 \mathrm{ka} \mathrm{BP}$ ); in BC04 (Figure 9), it is above $50 \%$ at $20 \mathrm{~cm}(16.4 \mathrm{ka} \mathrm{BP})$, then decreases and increases again from $17 \mathrm{~cm}$ to the core-top (14.7 ka BP-present), remaining high up to the core-top.

S. speculum var. coronata shows in contrast higher relative abundance in the bottom and top samples: in $\mathrm{BC} 02$, it displays high relative abundance at $31 \mathrm{~cm}(17.2 \mathrm{ka} \mathrm{BP})$ then decreases, while in $\mathrm{BC} 04$, it increases to peak values at $19 \mathrm{~cm}(15.8 \mathrm{ka} \mathrm{BP})$, then decreases. A slight increase in its percent values is observed in both $\mathrm{BC} 02$ and $\mathrm{BC} 04$ at $11 \mathrm{~cm}$ for $\mathrm{BC} 02$ and $8 \mathrm{~cm}$ for $\mathrm{BC} 04(9.5 \mathrm{ka} \mathrm{BP})$ and a further increase by $6.5 \mathrm{ka} \mathrm{BP}$, with higher percentage values in $\mathrm{BC} 02$ as compared to $\mathrm{BC} 04$. S. speculum var. coronata also includes morphologies with a large apical ring, typically indicated as var. minuta $[61,62]$. The latter constitutes up to $10 \%$ in $\mathrm{BC} 03$ and $\mathrm{BC} 04$ and up to $20-38 \%$ in the top samples of $\mathrm{BC} 02$. Finally, other varieties are represented by forms with an incomplete crown of apical spines and by aberrant morphologies, i.e., forms with an unclosed basal ring, doubled apical ring or forked spines: all these are usually a minor component of the $S$. speculum assemblage.

\subsubsection{Foraminifera}

Planktic and benthic foraminifera are present in $\mathrm{BC} 03$ and $\mathrm{BC} 04$; on the contrary, they are represented only by rare benthic agglutinated and fragmented taxa. Ecological significance of different taxa can be found in Supplementary S2.

Neogloboquadrina pachyderma (adults and juvenile tests) is the only planktic species recorded in the investigated sediments. In $\mathrm{BC} 03, \mathrm{~N}$. pachyderma varies from 1 to 818 specimens/g and is abundant from 36 to $28 \mathrm{~cm}$ (18-16 ka BP), reaching its maximum value at $31 \mathrm{~cm}(16.7 \mathrm{ka} \mathrm{BP})$ (Figure 11).

In this interval (18-16 ka BP), adult and juvenile specimens are recorded with a comparable abundance. In the sediments above $24 \mathrm{~cm}$ (younger than $14.1 \mathrm{ka} \mathrm{BP}), N$. pachyderma is very rare or absent and when present is only represented by adult forms. In $\mathrm{BC} 04, N$. pachyderma is present from 35 to $25 \mathrm{~cm}$ (21.5-19.2 ka BP) with a density ranging from 26 to 206 specimens/g (Figure 12). It reaches the maximum presence at $31 \mathrm{~cm}$ (20.6 ka $\mathrm{BP})$. Otherwise, it is nearly absent. In this box-core, only adult specimens are present. Tests of N. pachyderma are well-preserved and do not show dissolution or fragmentation.

Twenty-three benthic foraminifera species and twenty-one genera were identified (Supplementary S3). The most abundant species are Alabaminella weddellensis, Epistominella exigua, Cibicides lobatulus, Globocassidulina biora, Globocassidulina subglobosa, Nonionella iridea and Trifarina earlandi.

In BC03 (Figure 11), the benthic foraminifera density varies from $215(36 \mathrm{~cm}, 18.1 \mathrm{ka}$ $\mathrm{BP})$ to 1318 specimens $/ \mathrm{g}(31 \mathrm{~cm}, 16.7 \mathrm{ka} \mathrm{BP})$, in the lower portion of the box core (Figure 11). Their presence then rapidly decreases from $25 \mathrm{~cm}(14.1 \mathrm{ka} \mathrm{BP})$ and they are absent in the upper $3 \mathrm{~cm}$ (from $1.2 \mathrm{ka} \mathrm{BP}$ ). The most abundant species are T. earlandi (avg. 8\%), E. exigua (avg. 7\%), C. lobatulus (avg. 3\%), N. iridea (avg. 3\%), G. biora (avg. 3\%), A. weddellensis (avg. $2 \%$ ) and G. subglobosa (avg. 1\%). Miliammina earlandi, agglutinated taxon, is abundant from $25 \mathrm{~cm}(14.1 \mathrm{ka} \mathrm{BP})$ and is the only species present from 20 to $4 \mathrm{~cm}(11.2 \mathrm{ka} \mathrm{BP}$ to $1.7 \mathrm{ka} \mathrm{BP})$. E. exigua and A. weddellensis have a similar trend and are abundant from 36 to $28 \mathrm{~cm}$ (18.1 ka BP to $15.9 \mathrm{ka} \mathrm{BP}$ ) (Figure 11). In BC04, benthic species are less abundant and diversified than those of $\mathrm{BC} 03$. Their abundance reaches the maximum value of 14 specimens/g at $31 \mathrm{~cm}$ (20.6 ka BP) (Figure 12). The most abundant species are G. subglobosa (avg. 18\%), Lagena spp. (avg. 12\%) and E. exigua (avg. 4.4\%) (see Supplementary S3). Agglutinated taxa are represented by M. earlandi, which is present at around 11-15 cm (14 ka BP). Epistominella exigua and A. weddellensis occur at around 31-35 cm (21 ka BP). Globocassidulina subglobosa is present from 35 to $25 \mathrm{~cm}$ (21.5-19.2 ka BP). In BC04, the test fragmentation is very high (over $50 \%$ in almost the entire carbonate interval from 25 to $35 \mathrm{~cm}(21.5-19.2 \mathrm{ka} \mathrm{BP})$ (Figure 12). 


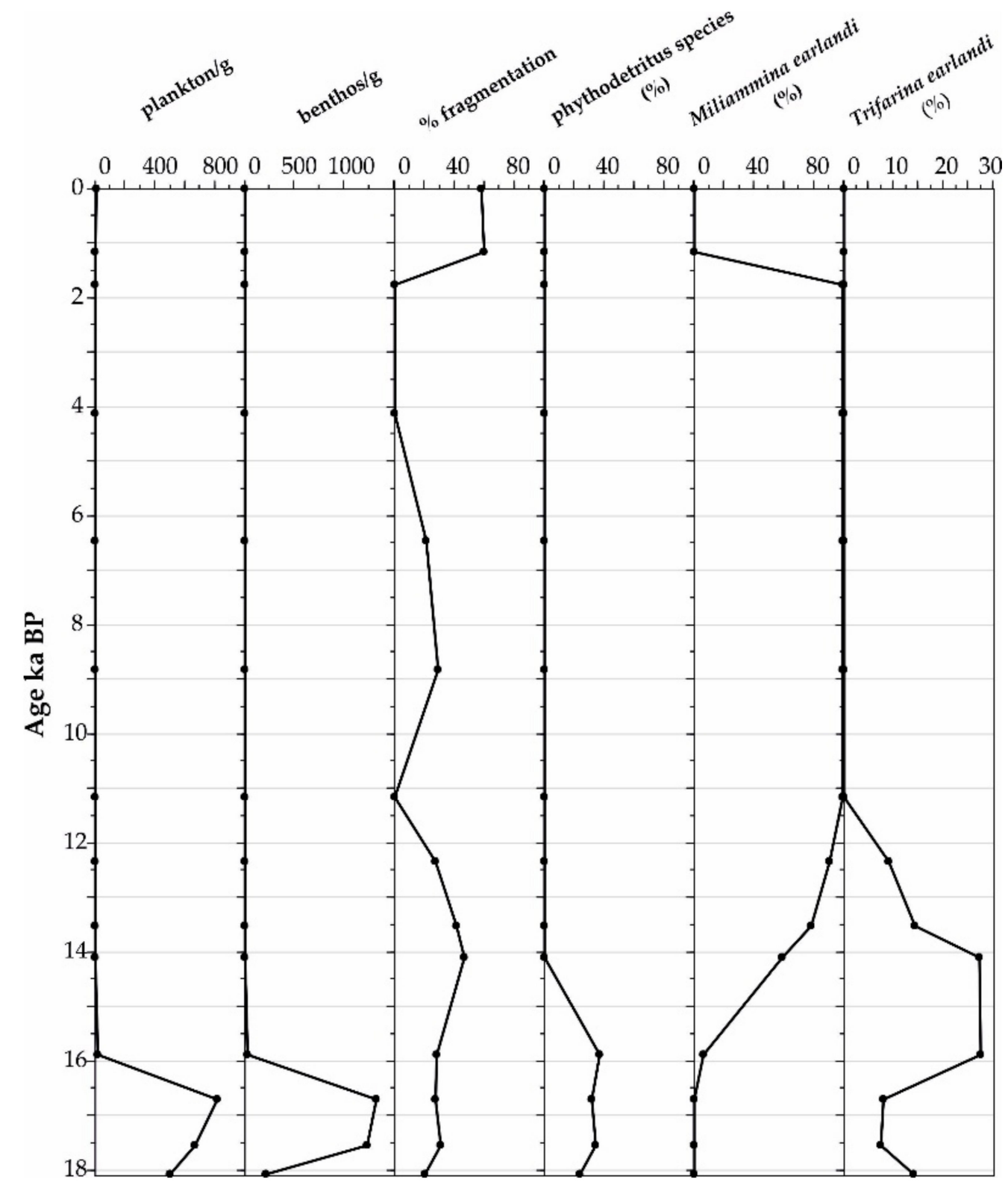

Figure 11. From left to right: down-core distribution in $\mathrm{BC} 03$ of planktic N. pachyderma and benthonic foraminifera (as the number of specimens per gram of dry sediment), fragmentation (\%), and relative abundance (\%) of benthic foraminifera. The phytodetritus species includes the \% of A. weddellensis and E. exigua. 


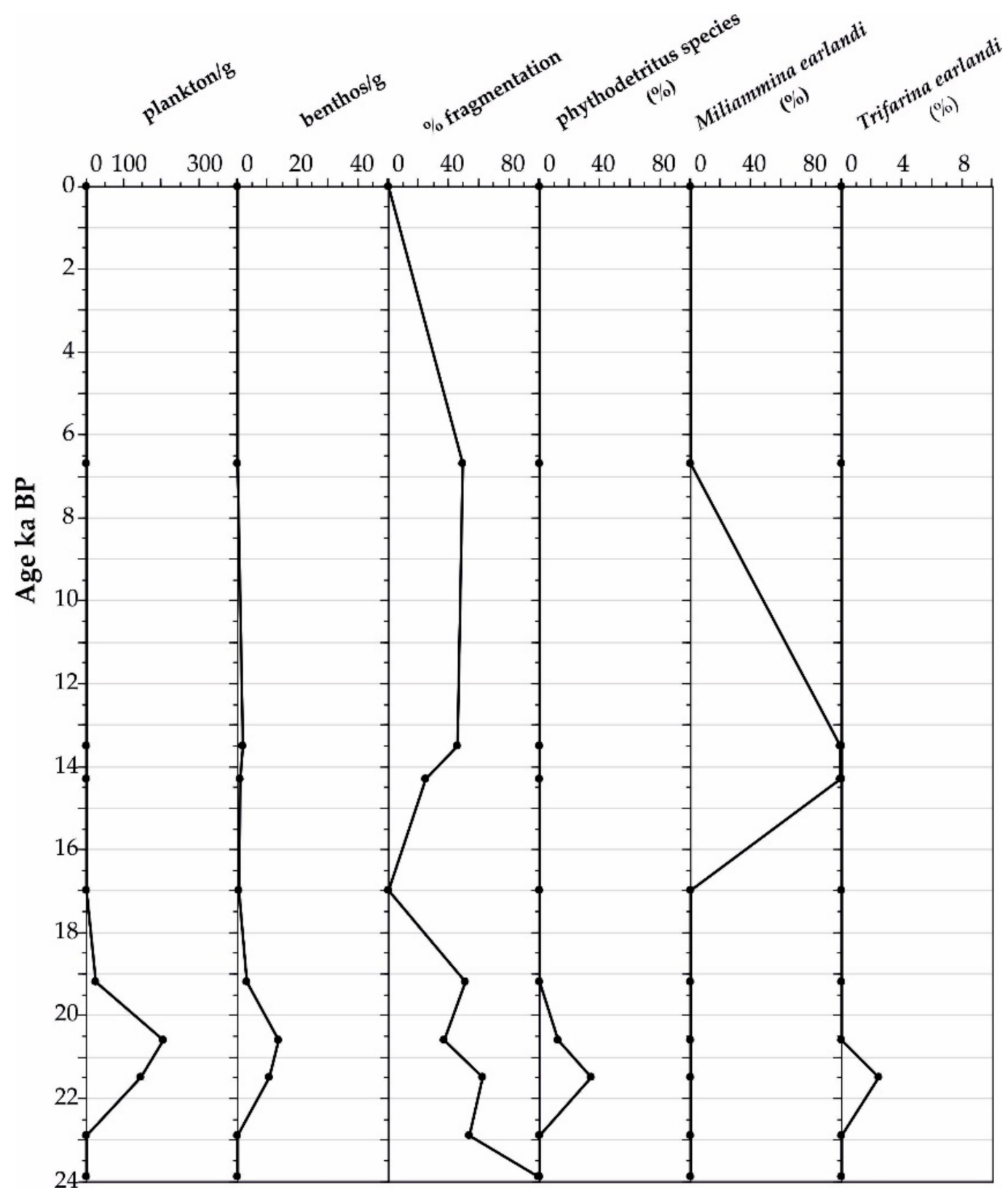

Figure 12. From left to right: down-core distribution in BC04 of planktic N. pachyderma and benthonic foraminifera (as the number of specimens per gram of dry sediment), fragmentation (\%), and relative abundance (\%) of benthic foraminifera. The phytodetritus species includes the \% of $A$. weddellensis and E. exigua.

\section{Discussion}

\subsection{Sedimentary Dynamics}

As previously observed by Hoffmann et al. [63], an important concern in interpreting sedimentary records is "whether the sortable silt reflects only current-driven sorting, or whether other vectors of sediment supply can bias the record". As observed in the box cores, IRD is a relevant sedimentary input and may influence grain size due to the delivery of unsorted material. Figure 4 demonstrates a very good fit of the samples from the Central Basin to the typical linear relationship linked to the selection of the SS according to McCave et al. [39]. Cluster 6 represents sediments mostly affected by the influence of the vertical flux due to IRD as found in BC02 and partially in BC03: these samples are those responsible for the bias in the relationship reported in Figure 4. Excluding cluster 6, the correlation coefficient improves from $r=0.89$ to $r=0.93$. 
The diagram also suggests the goodness of the clustering procedure, since the coarsening (or fining) sequence follows the linear trend, thus inferring the increasing (or reducing) effect of selectivity of the local currents in the sedimentary process affecting the Central Basin.

Given the above considerations, we can deduce that the dominant process is a sedimentation controlled by currents, which tend to modulate intensity in time and space, as seen by the grain size trend (stepwise fining or coarsening) according to different SS modes. The grain sizes conserve a marked modal peak (primary SS subpopulation) which can shift in the order of $5-10 \mu \mathrm{m}$ from $10 \mu \mathrm{m}$ to $55 \mu \mathrm{m}$. In terms of mean SS each shift of clusters (excluding cluster 6) implies a progressive increase of 1.6 to $2.4 \mu \mathrm{m}$. If we consider the sensitivity (relationship between flow speed and mean SS) proposed by McCave et al. [64], the sedimentological changes linked to each cluster step are due to increase in the current speed between 2.2 and $3.3 \mathrm{~cm} \mathrm{~s}^{-1}$. Thus, the fining or coarsening grain size trend, which involves the current-related grain size clusters, implies an overall flow speed variation of ca $7.5 \mathrm{~cm} \mathrm{~s}^{-1}$.

The mostly regular presence of SS, the lack of sedimentary structures within the sampled thickness, accompanied by low and variable sedimentary rates (between 0.74 and $4.33 \mathrm{~cm} \mathrm{ky}^{-1}$ ) not related to changes in grain size, do exclude turbidity currents as well as intermittent sediment supplies.

The sedimentary records seem more likely to be associated to a continuous flux of glacigenic sediments, rich in silt, delivered by the Ross Ice shelf [65], maintained in suspension by currents up to the shelf break and further moved towards the Central Basin, where they are captured by the westerly contour-current. The specific physiography of the Central Basin is likely to cause a local gyre, as inferred by the pattern of currents resulting from the longline fishing analysis carried out by Richard et al. [66]. Despite the limitation of the method, longline data suggest a complex movement of the water masses directly around and west of Iselin Bank (Figure 1), due to the control given by the topographic highs. These are likely to induce a circular current pattern inside the Central Basin responsible for the partitioning of the sediments according to the specific places, more or less exposed to the velocity gradient. The above hypothesis could explain the difference in the stratigraphic signal, as well as the different current intensities among the different cores, as recorded by the SS proxy.

The contourite pattern is altered by the vertical flux linked to the IRD, characterising the entire stratigraphic record. Although icebergs and sea ice are currently sources of IRD to the slope sediments, the presence of IRD in the sediment does not affect the typical grain size signal due to the current selection. The similar vertical pattern of grain size sorting in $\mathrm{BC} 02$ and $\mathrm{BC} 03$ is an interesting aspect that we can only discuss as a mere hypothesis. These two box cores seem to be correlated according to a typical downcurrent fining, considering $\mathrm{BC} 03$ as the more exposed site and $\mathrm{BC} 02$ as a basin sink. This implies that the current would flow from $\mathrm{BC} 03$ to $\mathrm{BC} 02$, thus inverting the original westerly direction while decreasing its velocity. We are unable to confirm this pathway, but future investigations may or may not confirm this hypothesis.

\subsection{Cryptotephra: Correlation with Volcanic Source}

The Glass composition of BC04 38-39 cryptotephra plot in the compositional field of phonolite to trachyte and overlap the compositions of the products of Mount Rittmann $[57,58,60,67]$ (Figure 7c,d). These can be clearly distinguished from the pyroclastic products of the other volcanic complexes of North Victoria Land namely Mount Melbourne and the Pleiades volcanoes or from the products of the Mt Erebus volcano, which is located further south than the Central Basin. BC04 38-39 cryptotephra shares a geochemical affinity with several marine tephra and cryptotephra layers recently found interbedded in the Holocene-late Pleistocene sediments of the Ross Sea and in ice records $[57,60,61]$. The glass compositions of $\mathrm{BC} 04$ cryptotephra match those of the 1254 C.E. (or $1252 \pm 2$ ) tephra from Mount Rittmann widespread in the marine sediments from Cape Hallett [31,57] and in the ice records of the entire West Antarctica [58,68-71]. BC04 38-39 cryptotephra 
compositions also match very well with the composition of $11.1 \pm 1.4$ ka Aviator tephra (AVT tephra) found in the marine sediments of the Aviator Basin ([60], and again derived from the Mount Rittmann. Finally, except for slight differences in $\mathrm{SiO}_{2}$ and $\mathrm{Al}_{2} \mathrm{O}_{3}$ content, BC04 38-39 cryptotephra shares a broad geochemical affinity, with two marine tephra layers found in the western Ross Sea constrained by ${ }^{40} \mathrm{Ar}^{-39} \mathrm{Ar}$ ages at $23.7 \pm 5.3 \mathrm{ka} \mathrm{BP}$ (ANTA02-NW2-0-13) and 21.2 $\pm 6.4 \mathrm{ka}$ BP (ANTA02-NW31-42-61), respectively [61], and again correlated to the explosive activity of Mount Rittmann [58].

Unfortunately, it was not possible to directly date BC04 38-39 marine cryptotephra using the radiometric method due to the extremely fine grain size of the particles and the very low abundance of $\mathrm{K}$-feldspar crystals directly derived from the tephra. However, as shown in Figure 2 the age of $22.0 \mathrm{ka}$ BP was obtained by AMS dating of AIOM in BC04 at $37 \mathrm{~cm}$, on top of the cryptotephra. Thus, we can attribute to BC04 38-39 cryptotephra a minimum age slightly older than $22 \mathrm{ka}$ BP. This age is in good agreement with those determined for the two marine tephra found interbedded in the marine sediments of the Drygalski Basin [60], dated by the ${ }^{40} \mathrm{Ar}^{39} \mathrm{Ar}$ method between $23.7 \pm 5.3 \mathrm{ka}$ (ANTA02-NW20-13) and 21.2 $\pm 6.4 \mathrm{ka}$ BP (ANTA02-NW31-42-61) mentioned above.

In addition to slight differences in the major element composition, we suggest that BC04 38-39 cryptotephra and ANTA02-NW2-0-13 and ANTA02-NW31-42-61 marine tephra layers could be derived from the same eruption and represent the very distal and medialdistal deposits, respectively, of a highly energetic explosive eruption of Mount Rittmann which occurred at ca. $22 \mathrm{ka}$ BP.

\subsection{Paleoenvironment Interpretation}

Radiocarbon datings are consistent with their stratigraphic position and therefore the effect of sedimentary reworking is negligible.

On the basis of the age model result, the studied sediments recorded the last $24 \mathrm{ka}$, which correspond to a part of the Last Glacial Maximum (LGM) (26.5-19 ka BP, sensu Clark et al. [72]), the subsequent deglaciation, and the onset of the Holocene. This offers us the possibility to discuss the main phases occurring during this period which are still under debate in terms of its timing, style, and forcing factors (e.g., [9]).

$\mathrm{BC} 04$ sampled the oldest sedimentary sequence and allowed for an inference of the environmental and oceanographic condition during the LGM, while $\mathrm{BC} 02$ and $\mathrm{BC} 03$ record the more recent period and allow for a better understanding of the environmental change during the early stage of the deglaciation and the following Holocene.

The downcore variation in the relative abundance of diatom, silicoflagellate and foraminifera contents and the grain size and tephra data allows for the recognition of three different sedimentary units: Unit 1 (24 ka BP to $17 \mathrm{ka} \mathrm{BP}$ ), Unit 2 (17 ka BP to $10.2 \mathrm{ka} \mathrm{BP}$ ), and Unit 3 (10.2 ka BP to present). In Figure 13 we present a schematic sketch of processes occurring in the three sedimentary units. 

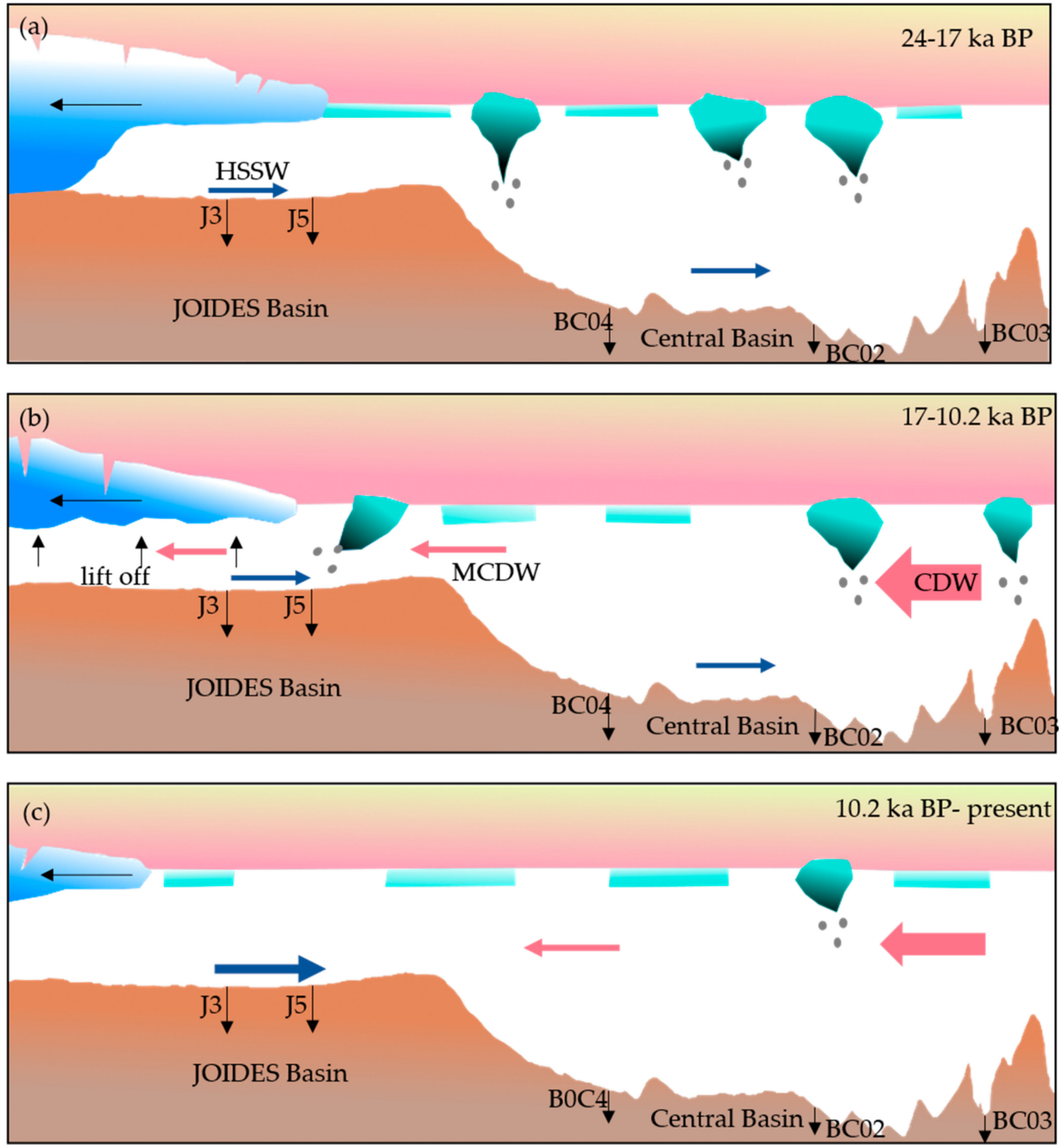

Figure 13. Schematic sketch of the (a) glacial period (b) deglacial period and (c) Holocene period in the Central Basin. The pink arrow indicates Circumpolar Deep Water (CDW), the blue arrow indicates High Salinity Shelf Water (HSSW).

\subsubsection{Unit 1: From 24 ka BP to $17 \mathrm{ka} \mathrm{BP/Late} \mathrm{Pleistocene}$}

During the LGM (global ice-sheet expansion from 26.5 to $19 \mathrm{ka} \mathrm{BP}$, according to Clark et al. [72]), the Ross Ice shelf was grounded on the seafloor (Ice Sheet) near the edge of the continental shelf at the latitude of Coulman Island (Figure 1) [5,9,73-75]. Even if the ice sheet expansion is well documented, the ice shelf cover and its extension still remain poorly constrained. The authors of [9] proposed a model of ice shelf extension starting from $20 \mathrm{ka} \mathrm{BP}$ and suggested that the ice shelf covered until the outer sector of the JOIDES basin but the Central Basin has not yet been examined.

In the studied area, Unit 1 (24 ka BP to $17 \mathrm{ka} \mathrm{BP}$ ) is well represented in BC04 while in $\mathrm{BC} 02$ and $\mathrm{BC} 03$ only the latest portion of this unit was sampled.

This unit is characterised by silty sediments for the most belonging to cluster 3 (BC04), thus suggesting a dominant contour current able to control the sedimentary processes. The unit features a high gravel content and abundant sand derived from IRD supply. The vertical flux locally tends to alter the current-controlled signal, as highlighted by the presence of cluster 6 in the topmost part of the unit (18-17 ka BP) in BC02 and BC03.

Low ADA and absence of silicoflagellates in this interval are a consequence of high terrigenous supply due to strong glacial influence. In this period, the high relative percentage 
of E. antarctica which indicates iron enrichment due to ice melting (see Supplementary S2) indicates an environment dominated by iceberg transit and iceberg melting.

The relatively high percentage of $F$. obliquecostata and A. actinochilus among diatoms and S. speculum var. coronata (only detected at $17.2 \mathrm{ka} \mathrm{BP}$ in BC02) among silicoflagellates indicate the presence of seasonal sea ice (see Supplementary S2). In BC04, the co-presence of cold and sea ice indicators with T. antarctica indicates its vicinity to the ice shelf edge [75] and suggests the proximity to the calving zone [76-78], as well as the ice shelf destabilisation.

Starting from $21 \mathrm{ka} \mathrm{BP}$, the occurrence of calcareous foraminifera is recorded at the site (BC04) closer to the JOIDES Basin. They are characterised by the planktic N. pachyderma (only adult tests) and scattered specimens of benthic taxa (Figure 12). Even if the density of N. pachyderma is significantly high at $20.5 \mathrm{ka} \mathrm{BP}$ (Figure 12), the contemporary presence of numerous fragmented tests (mean fragmentation $51 \%$ ), led us to consider these foraminifera as transported/reworked. This consideration is in agreement with the influence of bottom currents seen in this period.

A further recovery of calcareous-sediment-rich intervals is also recorded at the site of Hallett Ridge site (BC03), from 18.1 to $15.9 \mathrm{ka}$ BP. In contrast to BC04, the foraminifera here are generally well preserved. They are represented by the planktic $N$. pachyderma, including both adult and juvenile forms. Neogloboquadrina pachyderma is able to live in polar oceans, need glacial-free conditions to better proliferate and to reach the reproduction phase [79]. The co-presence of both growth stages of $N$. pachyderma can be the effect of accumulation during different seasons [78]. Similarly, we interpret that their occurrence is indicative of a period characterised by the beginning of open water with seasonal sea ice conditions.

At the same time, the benthic foraminifera are abundant and are mainly represented by E. exigua, A. weddellensis, Nonionella spp., and subordinately by C. lobatulus, G. biora, G. subglobosa and T. earlandi. This benthic foraminifera association is normally used to represent sub-ice shelf environments, from proximal to distal, although the presence of $A$. weddellensis and E. exigua suggests a more open marine environment [80]. These two small species could also indicate the occasional influence of CDW for this area, as suggested by $[80,81]$.

Similar results of carbonate-rich intervals have been reported either by [82] in the eastern Ross Sea continental margin in a time period spanning from 28.2 to $17.2 \mathrm{ka} \mathrm{BP} \mathrm{(as}$ uncorrected ages) or by [15] and by [78] in the western Ross Sea continental margin, at around $20 \mathrm{ka} \mathrm{BP}$. Authors of [82] suggested that this carbonate layer was deposited under a destabilisation of the Ross ice shelf-sea ice system likely caused by meltwater pulse (MWP) at $19 \mathrm{ka}$ BP. Authors of [15] suggested that the deposition of carbonate (mainly planktic foraminifera) layer occurred during the glacial period due to the influence of grounded ice sheets on the continental shelf that inhibited the formation of corrosive shelf water and/or due to intense bottom current that allowed preservation by restricting fine material deposition. In our studied area the presence of carbonate is recorded only in those sites (BC03 and BC04) located on two bathymetric highs, whereas carbonates are absent in BC02 due to the greater depth.

To summarise, the co-presence of benthic foraminifera and diatom cold water indicator F. obliquecostata and T. antarctica, in agreement with the abundance of N. pachyderma, F. curta and $A$. actinochilus, suggests an environment near the ice shelf calving zone characterised by the presence of IRD and the development of a seasonal sea ice condition, and also confirmed by the presence of the cryptotephra layer in BC04 at $22 \mathrm{ka} \mathrm{BP.}$

The same environmental condition is also reported as a result of the analysis of core J3 collected in the outer section of the JOIDES Basin [25], where the granulated facies representing a lift-off zone or the presence of thin water film [73] is coeval to our unit. The sediments deposited in the Central Basin were therefore likely deposited under strong glacial influence and in the vicinity of the ice shelf calving zone (sensu [77]), as also proposed by $[11,15]$ at nearby locations.

The schematic depositional environment during unit 1 is shown in Figure 13a. 


\subsubsection{Unit 2: From 17 ka BP to 10.2 ka BP/Late Pleistocene-Early Holocene}

The Early Deglacial in Antarctica is reported starting from 22 to $21 \mathrm{ka}$ BP in the West Antarctic Ice Sheet divide Ice core (WDC) (West Antarctic Ice Sheet (WAIS) Divide Project members, 2013 [82]). In contrast different studies based on model and ice core data (Epica Dome C) have hypothesised that the atmospheric warming that drove the deglaciation, following the LGM maximum ice extent, began at $18 \mathrm{ka}$ BP [83-88]. The timing of the ice sheet and consequently ice shelf retreat did not start at the same time in the Antarctic region [5,88-91]. Regarding the western sector of the Ross Sea, the maximum extension of glaciers reached the mid-outer shelf of the JOIDES Basin during the LGM $[5,73]$ and the open water condition began to develop at about $14 \mathrm{ka} \mathrm{BP} \mathrm{[9].}$

In our sediments the first evidence of decreasing glacial influence is demonstrated by the inflow of warm waters. This occurs at $\sim 17 \mathrm{ka} \mathrm{BP}$ in the two offshore sites (BC02 and $\mathrm{BC} 03$ ), and then in $\mathrm{BC} 04$, in which the inflow of warm water occurred from $\sim 16 \mathrm{ka} B P$.

In this unit we detected the maximum values of ADA and ASA as previously reported in studies performed on cores from the northwest Ross Sea cores $[11,15,25,78,92]$. The increase in siliceous microfossil concentration testifies to an increase in primary productivity, also indicated by the presence of the phytodetritus benthic foraminifera E. exigua [93]. The change in productivity is caused by the continuous inflow of oceanic warm water and less terrigenous supply due to ice shelf retreat and thus supports the hypothesis of ameliorate climate conditions.

This micropaleontological content matches with siltier sediments and the prevalence of cluster 2 (BC03 and $\mathrm{BC} 04$ ) and cluster 1 (BC02) representative of very slow currents, with the exception of the timing interval 16-15 ka BP in $\mathrm{BC} 03$ where cluster 3, representative of a more intense current, prevails in agreement with the peak of T. earlandi. The beginning of the deglaciation phase, recorded in the three box cores, is marked by the replacement of the cold and sea ice diatoms by the open water taxa, F. kerguelensis among diatoms and, the open ocean varieties of S. speculum among silicoflagellates (see Supplementary S2). In the offshore sites (BC02 and $\mathrm{BC} 03$ ), the increase in open ocean diatom and silicoflagellates (see Supplementary S2) reached at $16.5 \mathrm{ka} \mathrm{BP}$ and corresponds to a drop in ice-related species. In contrast, in the site (BC04) closer to the continental shelf, the increase in open ocean species is interrupted at $16 \mathrm{ka} \mathrm{BP}$ by an increase in ice-related species (F. obliquecostata, A. actinochilus and S. speculum var. coronata) and the percent maxima of $F$. kerguelensis reached at 14.5-14 ka BP. In the offshore site BC03, the foraminifera strongly decreased from $16 \mathrm{ka}$ BP. Though considerably diminished in absolute abundance, they are still represented by the significant presence of $M$. earlandi, which becomes the only foraminifera present from $11.2 \mathrm{ka} \mathrm{BP}$ and above.

This agglutinated taxon has been documented in the diatomaceous sediments of the Ross Sea troughs by $[54,80,94]$ (as $M$. arenacea) during the Late Pleistocene-Holocene transition. The exclusive presence M. earlandi and the disappearance of the calcareous foraminifera are normally related to the lower carbonate ion concentration in the deep water, presumably under the influence of the HSSW [14,80].

As pointed out by [30], high abundances of $F$. kerguelensis, are probably due to the intrusion of the warm and nutrient-rich CDW. The correlation with two cores (ANTA99-cJ5 and ANTA99-cJ3 [25] from the JOIDES basin allow us to identify the same F. kerguelensis abundances at $13.5 \mathrm{ka}$ BP. This correlation highlighted that the CDW intrusion began from offshore to the continental shelf as well as the increasing distance from the ice shelf calving zone.

Unit 2 thus represents the start of the Deglaciation characterised by the inflow of CDW into the Central Basin and the retreat of the ice shelf onto the JOIDES Basin. The CDW intrusion is first recorded at the outer Central Basin sites and then at the site near the continental shelf margin (Figure 13b). 


\subsubsection{Unit 3: From 10.2 ka BP to Present}

The Holocene period in the Antarctic region is characterised by the AIS retreat in response to the warming ocean and an increase in temperature [87]. During the Holocene, the ice sheet rapidly retreated from the Ross Sea [5] and this led to the establishment of seasonal sea ice. In this unit the sediments show a coarsening trend, suggesting an increase in the contour current velocity.

The decrease in ADA and ASA content recorded in both BC02 and BC04 since $10.2 \mathrm{ka}$ BP documents unfavourable conditions for phytoplankton bloom. The decreased abundance of CRS, especially in the offshore site, reflects the increasing distance of the ice shelf edge, as already observed during the late phase of deglaciation on the Antarctic Peninsula (Barbara et al., 2010), due to the decreased influence of nutrient-rich water from the melting ice shelf.

In the JOIDES Basin, the increase in ice-related species ( $F$. curta and F. obliquecostata) is observed from $8.2 \mathrm{ka}$ BP [30] and correlates with an increase in ssNa (sea salt Sodium) in ice cores (TALDICE and Taylor Dome) [30], indicating the establishment of a seasonal sea ice cycle and the sea ice extent due to the ice shelf retreats away from the outer sector of the JOIDES Basin. In this time period the JOIDES basin and the Ross Sea Embayment were fully opened as suggested by [95] and later by [30].

As already observed in the previous unit from the early Holocene onwards, calcareous foraminifera are nearly absent in Unit 3 as well and the only benthic species present is M. earlandi. The presence of this agglutinated taxon together with the percentage values of $F$. kerguelensis indicates the maintenance of open water conditions $[54,80,94-96]$ at least until $6.5 \mathrm{ka}$, even though a slight increase and oscillating abundance of ice-related and cold-water species (F. obliquecostata, E. antarctica, and S. speculum var. coronata) are observed, especially in the offshore site, suggesting a decreased inflow of CDW. A slight increase in $P$. sulcata from $10.2 \mathrm{ka} \mathrm{BP}$ indicates the onset of bottom transport from the shelf and could coincide with the renewed production of HSSW due to wind forcing and sea ice formation.

An increase in sea ice-related species (F. curta, A. actinochilus and S. speculum var. coronata) and cold-water-related species (F. obliquecostata) is observed from $6.5 \mathrm{ka} \mathrm{BP}$ and is associated with low ADA and ASA, low CRS, and a gradual decrease in F. kerguelensis. However, the co-occurrence of open ocean and sea ice related species, along with a slight increase in the warm water diatom group point to conditions of seasonal rather than perennial sea ice and a prolonged open water season.

The presence of $P$. sulcata from 4 ka BP, particularly marked in $\mathrm{BC} 04$, indicates strengthening and persistent transport from bottom waters also confirmed by the dominance of the grain size found in cluster 5 .

The increase in sea-ice related diatom species together with S. speculum var. coronata is particularly significant in the last $2.5 \mathrm{ka}$ and is higher in the offshore site suggesting colder water conditions. In the same interval, $P$. sulcata is particularly abundant reflecting a stronger influence of the HSSW, whose formation can be related to the establishments of the Ross Sea polynya. Furthermore, the last $2 \mathrm{ka}$ BP is characterized the increase in sand and IRD content which may be related to the presence of icebergs, as evidenced by increased abundances of E. antarctica.

To summarise, integrated results suggest that Unit 3 represents the Holocene period characterised by the establishment of seasonal sea ice and intense bottom currents (Figure 13c).

\section{Conclusions}

Micropaleontological, sedimentological and cryptotephra analyses performed on three sediment box-cores allow for the reconstruction of the environmental and oceanographic changes during the LGM-deglacial-Holocene period in the Central Basin of the western Ross Sea.

Micropaleontological investigation allows for the recognition of three stratigraphic units. Unit 1 (from 24 to $17 \mathrm{ka} \mathrm{BP}$ ) is characterised by a strong glacial influence due to the vicinity to ice shelf calving zone, Unit $2(17-10.2 \mathrm{ka} \mathrm{BP})$ represents the progressive 
receding of the ice shelf calving zone due to CDW inflow. Unit 3 (10.2 ka BP to present) is characterised by the establishment of seasonal sea ice and a strengthening of the bottom current. Moreover, we suggest that the abrupt increase in F. kerguelensis may be viewed as an indicator of the beginning of deglaciation and the presence of $P$. sulcata in the offshore area may be viewed as an indicator of the presence of bottom current.

Grain size data highlighted a dominant process of sedimentation controlled by currents, which tended to modulate intensity over time and space, as testified by the grain size central tendency marked by different sortable silt modes. The specific physiography of the Central Basin is likely to cause a local gyre, thus inducing a circular pattern responsible for the partitioning of the sediment according to the specific places, more or less exposed to the velocity gradient.

Finally, this investigation allowed for the identification of a cryptotephra correlated with the explosive activity of Mount Rittmann and dated at c. $22 \mathrm{ka}$ BP. This further confirms the occurrence of highly energetic explosive activity at this volcano in the Late Pleistocene. In addition, this cryptotephra provides a new chronostratigraphic marker for the future dating, correlation and synchronisation of the geological archive in this area.

Supplementary Materials: Supplementary materials can be found at https://www.mdpi.com/ article/10.3390/geosciences11040155/s1.

Author Contributions: Conceptualisation E.C. and F.T.; micropaleontological analyses R.M. and A.G. (foraminifera), F.T. (diatoms) and E.M. (silicoflagellates); grain size, M.B. and A.G.; tephra analyses, A.D.R., P.D.C. and B.S.; G.K. organised the ${ }^{14}$ C dating at AWI, input to methodology, data validation; age model, R.M.; interpretation of micropaleontological content, F.T., R.M., E.M.; grain size interpretation, E.C. and G.F.; L.C. and C.M. contributed to micropaleontological interpretation, wrote and revised the original manuscript. Project Leaders, funding acquisition, E.C. and B.-K.K. All authors have read and agreed to the published version of the manuscript.

Funding: This work was designed in the framework of the STREAM project. This project is cofunded by a grant from the Italian Ministry of Foreign Affairs and International Cooperation and the National Research Foundation of Korea (Korea-Italy Joint Research Program) and partly by KOPRI project (21090).

Institutional Review Board Statement: Not applicable.

Informed Consent Statement: Not applicable.

Data Availability Statement: Micropaleontological data are available on request from the corresponding author. These data are not publicly available as they are objects of PhD thesis. The other data are contained within the article.

Acknowledgments: We thank the technicians, captain, and crew of IBRV Araon for their efforts in obtaining sediment samples and geophysical data during the ANA03B expedition. We would like to thank the Italian PNRA (Progetto Nazionale di Ricerca in Antartide) and KOPRI (Korean Polar Research Institute) for funding the campaign. This research used samples provided by the Sorting Center-Trieste Section of the Museo Nazionale dell'Antartide-and it is developed in the framework of the STREAM Project (Late Quaternary evolution of the ocean-ice sheet interactions: the record from the Ross Sea continental margin (Antarctica). EC and BK wish to express their appreciation to the Italian Ministry of Foreign Affairs and International Cooperation (MAECI PGR 00822 and 01060) and PNRA project (2010/A2.07), and the National Research Foundation of Korea (2019K1A3A1A25000116) and KOPRI project (21090), respectively. This is contribution number 2047 of the Marine Science Institute-CNR, Bologna. Many thanks to Karolyn Close for the linguistic revision. We are grateful to the three anonymous reviewers for their suggestions on how to improve the manuscript.

Conflicts of Interest: The authors declare no conflict of interest. 


\section{References}

1. Camerlenghi, A.; Crise, A.; Pudsey, C.J.; Accerboni, E.; Laterza, R.; Rebesco, M. Ten-month observation of the bottom current regime across a sediment drift of the Pacific margin of the Antarctic Peninsula. Antarct. Sci. 1997, 9, 426-433. [CrossRef]

2. Rebesco, M.; Camerlenghi, A.; Geletti, R.; Canals, M. Margin architecture reveals the transition to the modern Antarctic ice sheet ca. 3 MAa. Geology 2006, 34, 301-304. [CrossRef]

3. Kim, S.; De Santis, L.; Hong, J.K.; Cottlerle, D.; Petronio, L.; Colizza, E.; Kim, Y.-G.; Kang, S.-G.; Kim, H.J.; Kim, S.; et al. Seismic stratigraphy of the Central Basin in northwestern Ross Sea slope and rise, Antarctica: Clues to the late Cenozoic ice-sheet dynamics and bottom-current activity. Mar. Geol. 2018, 395, 363-379. [CrossRef]

4. Castagno, P.; Capozzi, V.; DiTullio, G.R.; Falco, P.; Fusco, G.; Rintoul, S.R.; Spezie, G.; Budillon, G. Rebound of shelf water salinity in the Ross Sea. Nat. Commun. 2019, 10, 5441. [CrossRef] [PubMed]

5. Anderson, J.B.; Conway, H.; Bart, P.J.; Witus, A.E.; Greenwood, S.L.; McKay, R.M.; Hall, B.L.; Ackert, R.P.; Licht, K.; Jakobsson, M.; et al. Ross Sea paleo-ice sheet drainage and deglacial history during and since the LGM. Quat. Sci. Rev. 2014, 100, 31-54. [CrossRef]

6. Halberstadt, A.R.W.; Simkins, L.M.; Greenwood, S.L.; Anderson, J.B. Past ice-sheet behaviour: Retreat scenarios and changing controls in the Ross Sea, Antarctica. Cryosphere 2016, 10, 1003-1020. [CrossRef]

7. McGlannan, A.J.; Bart, P.J.; Chow, J.M.; DeCesare, M. On the influence of post-LGM ice shelf loss and grounding zone sedimentation on West Antarctic ice sheet stability. Mar. Geol. 2017, 392, 151-169. [CrossRef]

8. Lee, J.I.; McKay, R.M.; Golledge, N.R.; Yoon, H.I.; Yoo, K.-C.; Kim, H.J.; Hong, J.K. Widespread persistence of expanded East Antarctic glaciers in the southwest Ross Sea during the last deglaciation. Geology 2017, 45, 403-406. [CrossRef]

9. Prothro, L.O.; Majewski, W.; Yokoyama, Y.; Simkins, L.M.; Anderson, J.B.; Yamane, M.; Miyairi, Y.; Ohkouchi, N. Timing and pathways of East Antarctic Ice Sheet retreat. Quat. Sci. Rev. 2020, 230, 106166. [CrossRef]

10. Bart, P.J.; Cone, A.N. Early stall of West Antarctic Ice Sheet advance on the eastern Ross Sea middle shelf followed by retreat at 27,500 ${ }^{14}$ C year BP. Palaeogeogr. Palaeoclim. Palaeoecol. 2012, 335-336, 52-60. [CrossRef]

11. Tolotti, R.; Salvi, C.; Salvi, G.; Bonci, M.C. Late Quaternary climate variability as recorded by micropaleontological diatom data and geochemical data in the Western Ross Sea, Antarctica. Antarct. Sci. 2013, 25, 804-820. [CrossRef]

12. Frank, T.D.; James, N.P.; Bone, Y.; Malcolm, I.; Bobak, L.E. Late Quaternary carbonate deposition at the bottom of the world. Sediment. Geol. 2014, 305, 1-16. [CrossRef]

13. Bart, P.J.; DeCesare, M.; Rosenheim, B.E.; Majewski, W.; McGLANNAN, A. A centuries-long delay between a paleo-ice-shelf collapse and grounding-line retreat in the Whales Deep Basin, eastern Ross Sea, Antarctica. Sci. Rep. 2018, 8, 12392. [CrossRef] [PubMed]

14. Melis, R.; Salvi, G. Foraminifer and Ostracod Occurrence in a Cool-Water Carbonate Factory of the Cape Adare (Ross Sea, Antarctica): A Key Lecture for the Climatic and Oceanographic Variations in the Last 30,000 Years. Geoscience 2020, $10,413$. [CrossRef]

15. Kim, S.; Lee, J.I.; McKay, R.M.; Yoo, K.C.; Bak, Y.S.; Lee, M.K.; Roh, Y.H.; Yoon, H.I.; Moon, H.S.; Hyun, C.U. Late Pleistocene paleoceanographic changes in the Ross Sea-Glacial-interglacial variations in paleoproductivity, nutrient utilization, and deepwater formation. Quat. Sci. Rev. 2020, 239, 106356. [CrossRef]

16. Gales, J.; Rebesco, M.; De Santis, L.; Bergamasco, A.; Colleoni, F.; Kim, S.; Accettella, D.; Kovacevic, V.; Liu, Y.; Olivo, E.; et al. Role of dense shelf water in the development of Antarctic submarine canyon morphology. Geomorphology 2021, 372, 107453. [CrossRef]

17. Pollard, D.; DeConto, R.M. Modelling West Antarctic ice sheet growth and collapse through the past five million years. Nature 2009, 458, 329-332. [CrossRef] [PubMed]

18. Golledge, N.R.; Menviel, L.; Carter, L.; Fogwill, C.J.; England, M.H.; Cortese, G.; Levy, R.H. Antarctic contribution to meltwater pulse 1A from reduced Southern Ocean overturning. Nat. Commun. 2014, 5, 5107. [CrossRef] [PubMed]

19. DeConto, R.M.; Pollard, D. Contribution of Antarctica to past and future sea-level rise. Nature 2016, 531, 591-597. [CrossRef]

20. Colleoni, F.; De Santis, L.; Montoli, E.; Olivo, E.; Sorlien, C.C.; Bart, P.J.; Gasson, E.G.W.; Bergamasco, A.; Sauli, C.; Wardell, N.; et al. Past continental shelf evolution increased Antarctic ice sheet sensitivity to climatic conditions. Sci. Rep. 2018, 8, 11323. [CrossRef] [PubMed]

21. Holland, D.M.; Nicholls, K.W.; Basinski, A. The Southern Ocean and its interaction with the Antarctic Ice Sheet. Science 2020, 367, 1326-1330. [CrossRef]

22. Orsi, A.; Wiederwohl, T. A recount of Ross Sea waters. Deep Sea Res. II Top. Stud. Oceanogr. 2009, 56, 778-795. [CrossRef]

23. Smith, W.O., Jr.; Sedwick, P.N.; Arrigo, K.R.; Ainley, D.G.; Orsi, A.H. The Ross Sea in a Sea of Change. Oceanography 2012, 25, 90-103. [CrossRef]

24. Arndt, J.E.; Schenke, H.W.; Jakobsson, M.; Nitsche, F.O.; Buys, G.; Goleby, B.; Rebesco, M.; Bohoyo, F.; Hong, J.; Black, J.; et al. The International Bathymetric Chart of the Southern Ocean (IBCSO) Version 1.0-A new bathymetric compilation covering circum-Antarctic waters. Geophys. Res. Lett. 2013, 40, 3111-3117. [CrossRef]

25. Mezgec, K. Palaeoceanographic Changes during the Post-LGM Deglaciation Phase in the Polar Areas (Ross Sea-Antarctica and Barents Sea-Arctic Cases Studies). Ph.D. Thesis, University of Siena, Siena, Italy, 2015.

26. Wacker, L.; Lippold, J.; Molnár, M.; Schulz, H. Towards radiocarbon dating of single foraminifera with a gas ion source. Nucl. Instrum. Methods B 2013, 294, 307-310. [CrossRef] 
27. Stuiver, M.; Reimer, P.J.; Reimer, R.W. CALIB 7.1 [WWW Program]. 2018. Available online: http:/ / calib.org (accessed on 14 March 2018).

28. Reimer, P.; Bard, E.; Bayliss, A.; Beck, J.; Blackwell, P.; Ramsey, C.; Buck, C.E.; Cheng, H.; Edward, R.L.; Friedrich, M.; et al. IntCal13 and Marine13 Radiocarbon Age Calibration Curves 0-50,000 Years cal BP. Radiocarbon 2013, 55, 1869-1887. [CrossRef]

29. Hall, B.L.; Henderson, G.M.; Baroni, C.; Kellogg, T.B. Constant Holocene Southern-Ocean 14C reservoir ages and ice-shelf flow rates. Earth Planet. Sci. Lett. 2010, 296, 115-123. [CrossRef]

30. Mezgec, K.; Stenni, B.; Crosta, X.; Masson-Delmotte, V.; Baroni, C.; Braida, M.; Ciardini, V.; Colizza, E.; Melis, R.; Salvatore, M.C.; et al. Holocene sea ice variability driven by wind and polynya efficiency in the Ross Sea. Nat. Commun. 2017, 8, 1334. [CrossRef]

31. Tesi, T.; Belt, S.; Gariboldi, K.; Muschitiello, F.; Smik, L.; Finocchiaro, F.; Giglio, F.; Colizza, E.; Gazzurra, G.; Giordano, P.; et al. Resolving sea ice dynamics in the north-western Ross Sea during the last 2.6 ka: From seasonal to millennial timescales. Quat. Sci. Rev. 2020, 237, 106299. [CrossRef]

32. Andrews, J.T.; Domack, E.W.; Cunningham, W.L.; Leventer, A.; Licht, K.J.; Jull, A.J.T.; DeMaster, D.J.; Jennings, A.E. Problems and Possible Solutions Concerning Radiocarbon Dating of Surface Marine Sediments, Ross Sea, Antarctica. Quat. Res. 1999, 52, 206-216. [CrossRef]

33. Pudsey, C.J.; Murray, J.W.; Appleby, P.; Evans, J. Ice shelf history from petrographic and foraminiferal evidence, Northeast Antarctic Peninsula. Quat. Sci. Rev. 2006, 25, 2357-2379. [CrossRef]

34. Hillenbrand, C.-D.; Smith, J.A.; Kuhn, G.; Esper, O.; Gersonde, R.; Larter, R.D.; Maher, B.; Moreton, S.G.; Shimmield, T.M.; Korte, M. Age assignment of a diatomaceous ooze deposited in the western Amundsen Sea Embayment after the Last Glacial Maximum. J. Quat. Sci. 2009, 25, 280-295. [CrossRef]

35. Stuiver, M.; Reimer, P.J.; Reimer, R.W. CALIB 8.2 [WWW Program]. 2021. Available online: http://calib.org (accessed on 14 March 2018).

36. Heaton, T.; Köhler, P.; Butzin, M.; Bard, E.; Reimer, R.; Austin, W.; Ramsey, C.B.; Grootes, P.M.; Hughen, K.A.; Kromer, B.; et al. Marine20-The Marine Radiocarbon Age Calibration Curve (0-55,000 cal BP). Radiocarbon 2020, 62, 779-820. [CrossRef]

37. Friedman, G.M.; Sanders, J.E. Principles of Sedimentology; Wiley: New York, NY, USA, 1978; p. 792.

38. Folk, R.L.; Ward, W.C. Brazos River bar: A study in the significance of grain size parameters. J. Sediment. Res. 1957, 27, 3-26. [CrossRef]

39. McCave, I.; Andrews, J. Distinguishing current effects in sediments delivered to the ocean by ice. II. Glacial to Holocene changes in high latitude North Atlantic upper ocean flows. Quat. Sci. Rev. 2019, 223, 105902. [CrossRef]

40. McCave, I.N.; Manighettia, B.; Robinson, S.G. Sortables ilt and fine sediment size/composition slicing: Parameters for paleocurrent speed and palaeoceanography. Paleoceanography 1995, 10, 593-610. [CrossRef]

41. Hammer, Ø.; Harper, D.A.T.; Ryan, P.D. PAST: Paleontological Statistics Software Package for Education and Data Analysis. Palaeontol. Electron. 2001, 4, 4.

42. Rathburn, A.; Pichon, J.-J.; Ayress, M.; De Deckker, P. Microfossil and stable-isotope evidence for changes in Late Holocene palaeoproductivity and palaeoceanographic conditions in the Prydz Bay region of Antarctica. Palaeogeogr. Palaeoclim. Palaeoecol. 1997, 131, 485-510. [CrossRef]

43. Crosta, X.; Koç, N. Diatoms: From micropaleontology to isotope geochemistry. In Development in Marine Geology, 1, Proxies in Late Cenozoic Palaeoceanography; Hillaire-Marcel, C., De Vernal, A., Eds.; Elsevier: Amsterdam, The Netherlands, 2007 ; pp. 27-369.

44. Hasle, G.R.; Syversten, E.E. Marine diatoms. In Identifying Marine Phytoplankton; Thomas, C.R., Ed.; Academic Press: San Diego, CA, USA, 1997; pp. 5-385.

45. Armand, L.K. The Use of Diatom Transfer Functions in Estimating Sea-SURFACE temperature and Sea-Ice in Cores from the Southeast Indian Ocean. Ph.D. Thesis, Australian National University, Canberra, Australia, 1997.

46. Etourneau, J.; Collins, L.G.; Willmott, V.; Kim, J.-H.; Barbara, L.; Leventer, A.; Schouten, S.; Damsté, J.S.S.; Bianchini, A.; Klein, V.; et al. Holocene climate variations in the western Antarctic Peninsula: Evidence for sea ice extent predominantly controlled by changes in insolation and ENSO variability. Clim. Past 2013, 9, 1431-1446. [CrossRef]

47. Taylor, F.; Sjunneskog, C. Postglacial marine diatom record of the Palmer Deep, Antarctic Peninsula (ODP Leg 178, Site 1098) 2. Diatom assemblages. Paleoc. Paleoclim. 2002, 17, 8001. [CrossRef]

48. Malinverno, E. Extant morphotypes of Distephanus speculum (Silicoflagellata) from the Australian sector of the Southern Ocean: Morphology, morphometry and biogeography. Mar. Micropaleontol. 2010, 77, 154-174. [CrossRef]

49. Jordan, R.; McCartney, K. Stephanocha nom. nov., a replacement name for the illegitimate silicoflagellate genus Distephanus (Dictyochophyceae). Phytotaxa 2015, 201, 177-187. [CrossRef]

50. Malinverno, E.; Maffioli, P.; Gariboldi, K. Latitudinal distribution of extant fossilizable phytoplankton in the Southern Ocean: Planktonic provinces, hydrographic fronts and palaeoecological perspectives. Mar. Micropaleontol. 2016, 123, 41-58. [CrossRef]

51. Violanti, D. Taxonomy and distribution of recent benthic foraminifers from Terra Nova Bay (Ross Sea, Antarctica), Oceanographic Campaign 1987/1988. Palaeontogr. Ital. 1996, 83, 25-71.

52. Murray, J.W.; Pudsey, C.J. Living (stained) and dead foraminifera from the newly ice-free Larsen Ice Shelf, Weddell Sea, Antarctica: Ecology and taphonomy. Mar. Micropaleontol. 2004, 53, 67-81. [CrossRef]

53. Majewski, W. Benthic foraminiferal communities: Distribution and ecology in Admiralty Bay, King George Island, West Antarctica. Pol. Polar Res. 2005, 26, 159-214. 
54. Majewski, W.; Bart, P.J.; McGlannan, A.J. Foraminiferal assemblages from ice-proximal paleo-settings in the Whales Deep Basin, Eastern Ross Sea, Antarctica. Palaeogeogr. Paleoclim. Palaeoecol. 2018, 493, 64-81. [CrossRef]

55. Ellis and Messina Catalogues. Available online: http://www.micropress.org/ (accessed on 10 December 2020).

56. Le Bas, M.J.; Maitre, R.W.L.; Streckeisen, A.; Zanettin, B.; Rocks, I.S.O.T.S.O.I. A Chemical Classification of Volcanic Rocks Based on the Total Alkali-Silica Diagram. J. Pet. 1986, 27, 745-750. [CrossRef]

57. Di Roberto, A.; Colizza, E.; Del Carlo, P.; Petrelli, M.; Finocchiaro, F.; Kuhn, G. First marine cryptotephra in Antarctica found in sediments of the western Ross Sea correlates with englacial tephras and climate records. Sci. Rep. 2019, 9, 10628. [CrossRef]

58. Lee, M.J.; Kyle, P.R.; Iverson, N.A.; Lee, J.I.; Han, Y. Rittmann volcano, Antarctica as the source of a widespread $1252 \pm 2$ CE tephra layer in Antarctica ice. Earth Planet. Sci. Lett. 2019, 521, 169-176. [CrossRef]

59. Harpel, C.; Kyle, P.; Dunbar, N. Englacial tephrostratigraphy of Erebus volcano, Antarctica. J. Volcanol. Geotherm. Res. 2008, 177, 549-568. [CrossRef]

60. Di Roberto, A.; Albert, P.; Colizza, E.; Del Carlo, P.; Di Vincenzo, G.; Gallerani, A.; Giglio, F.; Kuhn, G.; Macrì, P.; Manning, C.; et al. Evidence for a large-magnitude Holocene eruption of Mount Rittmann (Antarctica): A volcanological reconstruction using the marine tephra record. Quat. Sci. Rev. 2020, 250, 106629. [CrossRef]

61. Del Carlo, P.; Di Roberto, A.; Di Vincenzo, G.; Bertagnini, A.; Landi, P.; Pompilio, M.; Colizza, E.; Giordano, G. Late PleistoceneHolocene volcanic activity in northern Victoria Land recorded in Ross Sea (Antarctica) marine sediments. Bull. Volcanol. 2015, 77, 36. [CrossRef]

62. Bukry, D. Silicoflagellate stratigraphy of offshore California and Baja California, Deep Sea Drilling Project Leg 63. In Initial Reports of the DSDP; Yeats, R.S., Haq, B.U., Pisciotto, K.A., Eds.; U.S. Goverment Printing Office: Washington, DC, USA, 1981; Volume 63, pp. 595-610.

63. Hoffmann, S.S.; Dalsing, R.E.; Murphy, C.S. Sortable silt records of intermediate-depth circulation and sedimentation in the Southwest Labrador Sea since the Last Glacial Maximum. Quat. Sci. Rev. 2019, 206, 99-110. [CrossRef]

64. McCave, I.N.; Thornalley, D.J.R.; Hall, I.R. Relation of sortable silt grain-size to deep-sea current speeds: Calibration of the 'Mud Current Meter'. Deep Sea Res. Part I Oceanogr. Res. Pap. 2017, 127, 1-12. [CrossRef]

65. Andrews, J.T.; Principato, S.M. Grain-size characteristics and provenance of ice-proximal glacial marine sediments. Geol. Soc. Lond. Spec. Publ. 2002, 203, 305-324. [CrossRef]

66. Richard, G.J.; Roberts, M.J.; Williams, M.J.; Dunn, A.; Smith, M.H. Mean circulation and hydrography in the Ross Sea sector, Southern Ocean: Representation in numerical models. Antarct. Sci. 2010, 22, 533-558. [CrossRef]

67. Armienti, P.; Tripodo, A. Petrography and chemistry of lavas and comagmatic xenoliths of Mt. Rittmann, a volcano discovered during the IV Italian expedition in Northern Victoria Land (Antarctica). Mem. Soc. Geol. Ital. 1991, 46, 427-451.

68. Dunbar, N.W.; Zielinski, G.A.; Voisins, D.T. Tephra layers in the Siple Dome and Taylor Dome ice cores, Antarctica: Sources and correlations. J. Geophys. Res. 2003, 108, 2374. [CrossRef]

69. Dunbar, N.W.; Kurbatov, A.V. Tephrochronology of the Siple Dome ice core, West Antarctica: Correlations and sources. Quat. Sci. Rev. 2011, 30, 1602-1614. [CrossRef]

70. Narcisi, B.; Petit, J.R.; Chappellaz, J. A 70 ka record of explosive eruptions from the TALDICE ice core (Talos Dome, East Antarctic plateau). J. Quat. Sci. 2010, 25, 844-849. [CrossRef]

71. Sigl, M.; Fudge, T.J.; Winstrup, M.; Cole-Dai, J.; Ferris, D.; McConnell, J.R.; Taylor, K.C.; Welten, K.C.; Woodruff, T.E.; Adolphi, F; et al. The WAIS Divide deep ice core WD2014 chronology-Part 2: Annual-layer counting (0-31 ka BP). Clim. Past 2016, 12, 769-786. [CrossRef]

72. Clark, P.U.; Dyke, A.S.; Shakun, J.D.; Carlson, A.E.; Clark, J.; Wohlfarth, B.; Mitrovica, J.X.; Hostetler, S.W.; McCabe, A.M. The Last Glacial Maximum. Science 2009, 325, 710-714. [CrossRef] [PubMed]

73. Domack, E.W.; Jacobson, E.A.; Shipp, S.; Anderson, J.B. Late Pleistocene-Holocene retreat of the West Antarctic Ice-Sheet system in the Ross Sea: Part 2-Sedimentologic and stratigraphic signature. Geol. Soc. Am. Bull. 1999, 111, 1517-1536. [CrossRef]

74. Bart, P.J.; Anderson, J.B.; Trincardi, F.; Shipp, S.S. Seismic data from the Northern Basin, Ross Sea, record extreme expansions of the East Antarctic ice sheet during the late Neogene. Mar. Geol. 2000, 166, 31-50. [CrossRef]

75. McKay, R.M.; Dunbar, G.B.; Naish, T.R.; Barrett, P.J.; Carter, L.; Harper, M. Retreat history of the Ross Ice Sheet (Shelf) since the Last Glacial Maximum from deep-basin sediment cores around Ross Island. Palaeogeogr. Palaeoclim. Palaeoecol. 2008, 260, $245-261$. [CrossRef]

76. Cunningham, W.L.; Leventer, A.; Andrews, J.T.; Jennings, A.E.; Licht, K.J. Late Pleistocene-Holocene marine conditions in the Ross Sea, Antarctica: Evidence from the diatom record. Holocene 1999, 9, 129-139. [CrossRef]

77. Smith, J.A.; Graham, A.G.C.; Post, A.L.; Hillenbrand, C.D.; Bart, P.J.; Powell, R.D. The marine geological imprint of Antarctic ice shelves. Nat. Commun. 2019, 10, 5635. [CrossRef]

78. Melis, R.; Capotondi, L.; Torricella, F.; Ferretti, P.; Geniram, A.; Hong, J.K.; Kuhn, G.; Khim, B.-K.; Kim, S.; Malinverno, E.; et al. Last Glacial Maximum to Holocene paleoceanography of the northwestern Ross Sea inferred from sediment core geochemistry and micropaleontology at Hallett Ridge. J. Micropalaeontol. 2021, 40, 15-35. [CrossRef]

79. Mikis, A.; Hendry, K.R.; Pike, J.; Schmidt, D.N.; Edgar, K.M.; Peck, V.; Peeters, F.J.C.; Leng, M.J.; Meredith, M.P.; Todd, C.L.; et al. Temporal variability in foraminiferal morphology and geochemistry at the West Antarctic Peninsula: A sediment trap study. Biogeosciences 2019, 16, 3267-3282. [CrossRef] 
80. Majewski, W.; Prothro, L.O.; Simkins, L.M.; Demianiuk, E.J.; Anderson, J.B. Foraminiferal Patterns in Deglacial Sediment in the Western Ross Sea, Antarctica: Life Near Grounding Lines. Paleoceanogr. Paleoclimatol. 2020, 35, 003716. [CrossRef]

81. Majewski, W.; Wellner, J.S.; Anderson, J.B. Environmental connotations of benthic foraminiferal assemblages from coastal West Antarctica. Mar. Micropaleontol. 2016, 124, 1-15. [CrossRef]

82. Bonaccorsi, R.; Quaia, T.; Burckle, L.H.; Anderson, R.F.; Melis, R.; Brambati, A. C-14 age control of pre- and post-LGM events using N. pachyderma preserved in deep-sea sediments (Ross Sea, Antarctica). In Proceedings of the 10th ISAES X, USGS, Santa Barbara, CA, USA, 26 September-1 October 2007.

83. WAIS Divide Project Members. Onset of deglacial warming in West Antarctica driven by local orbital forcing. Nature 2013, 500, 440-444. [CrossRef] [PubMed]

84. Jouzel, J.; Masson, V.; Cattani, O.; Falourd, S.; Stievenard, M.; Stenni, B.; Longinelli, A.; Johnsen, S.J.; Steffenssen, J.P.; Petit, J.R.; et al. A new 27 ky high resolution East Antarctic climate record. Geophys. Res. Lett. 2001, 28, 3199-3202. [CrossRef]

85. EPICA Community Members. One-to-one coupling of glacial climate variability in Greenland and Antarctica. Nature 2006, 444, 195-198. [CrossRef]

86. Jouzel, J.; Masson-Delmotte, V.; Cattani, O.; Dreyfus, G.; Falourd, S.; Hoffmann, G.; Minster, B.; Nouet, J.; Barnola, J.M.; Chappellaz, J.; et al. Orbital and millennial Antarctic climate variability over the last 800,000 years. Science 2007, 317, 793-796. [CrossRef]

87. Stenni, B.; Buiron, D.; Frezzotti, M.; Albani, S.; Barbante, C.; Bard, E.; Barnola, J.M.; Baroni, M.; Baumgartner, M.; Bonazza, M.; et al. Expression of the bipolar see-saw in Antarctic climate records during the last deglaciation. Nat. Geosci. 2011, 4, 46-49. [CrossRef]

88. Bostock, H.; Barrows, T.; Carter, L.; Chase, Z.; Cortese, G.; Dunbar, G.; Ellwood, M.; Hayward, B.; Howard, W.; Neil, H.; et al. A review of the Australian-New Zealand sector of the Southern Ocean over the last $30 \mathrm{ka}$ (Aus-INTIMATE project). Quat. Sci. Rev. 2013, 74, 35-57. [CrossRef]

89. Anderson, J.B.; Shipp, S.S.; Lowe, A.L.; Wellner, J.S.; Mosola, A.B. The Antarctic Ice Sheet during the Last Glacial Maximum and its subsequent retreat history: A review. Quat. Sci. Rev. 2002, 21, 49-70. [CrossRef]

90. Bentley, M.J.; Cofaigh, C.Ó.; Anderson, J.B.; Conway, H.; Davies, B.; Graham, A.G.C.; Hillebrand, C.D.; Hodgson, D.A.; Jamieson, S.S.R.; Larter, R.D.; et al. A community-based geological reconstruction of Antarctic Ice Sheet deglaciation since the Last Glacial Maximum. Quat. Sci. Rev. 2014, 100,1-9. [CrossRef]

91. Yokoyama, Y.; Esat, T.M.; Thompson, W.G.; Thomas, A.L.; Webster, J.M.; Miyairi, Y.; Sawada, C.; Aze, T.; Matsuzaki, H.; Okuno, J.; et al. Rapid glaciation and a two-step sea level plunge into the Last Glacial Maximum. Nature 2018, 559, 603-607. [CrossRef] [PubMed]

92. Maas, S.M. Last Glacial Maximum-Holocene Glacial and Depositional History from Sediment 1049 Cores at Coulman High beneath the Ross Ice Shelf, Antarctica. Master's Thesis, Victoria University of Wellington, Wellington, New Zealand, 2012; 114p.

93. Jorissen, F.J.; Fontanier, C.; Thomas, E. Paleoceanographical proxies based on deep-sea benthic foraminiferal assemblage characteristics. In Proxies in Late Cenozoic. Paleoceanography, Developments in Marine Geology, 1; Hillaire-Marcel, C., De Vernal, A., Eds.; Elsevier: Amsterdam, The Netherlands, 2007; pp. 263-325.

94. Melis, R.; Salvi, G. Late Quaternary foraminiferal assemblages from western Ross Sea (Antarctica) in relation to the main glacial and marine lithofacies. Mar. Micropaleontol. 2009, 70, 39-53. [CrossRef]

95. Baroni, C.; Orombelli, G. Abandoned penguin rookeries as Holocene paleoclimatic indicators in Antarctica. Geology 1994, 22, 23-26. [CrossRef]

96. Crosta, X.; Romero, O.; Armand, L.K.; Pichon, J.-J. The biogeography of major diatom taxa in Southern Ocean sediments: 2. Open ocean related species. Palaeogeogr. Palaeoclim. Palaeoecol. 2005, 223, 66-92. [CrossRef] 